\title{
Studying the Role of Political Competition in the Evolution of Government Size Over Long Horizons
}

J.Stephen Ferris, Soo-Bin Park and Stanley L. Winer

December 2007

CWPE 0774

Paper presented at the conference on "Institutions, Public Policy and Economic Outcomes" held in August 2007 and sponsored by the Economic and Social Research Council (grant no.RES 000-22-1743). 


\title{
Studying the Role of Political Competition in the Evolution of Government Size Over Long Horizons
}

\author{
J. Stephen Ferris* \\ stephen_ferris@carleton.ca \\ Soo-Bin Park* \\ soo-bin_park@carleton.ca \\ and \\ Stanley L. Winer** \\ stan_winer@carleton.ca
}

January 9, 2007

\begin{abstract}
* Department of Economics, Carleton University
** School of Public Policy and Department of Economics, Carleton University

All authors: 1125 Colonel By Drive, Ottawa Ontario, Canada, K1S 5B6
\end{abstract}

Earlier versions of this paper were presented at the Public Choice Society Meetings in Baltimore, March 2004, the European Public Choice Meetings in Durham U.K., April 2005, the IIPF Congress in Jeju South Korea in August 2005, at the Universities of Bocconi, Catania, Pisa and Turin in June 2005, at the National University of Cordoba in September 2005, and at the CES public economics conference in Munich, April 2006. Our thanks to Keith Acheson, Massimo Bourdignon, Christian Bjornskov, Giorgio Brosio, Mario Ferrero, Vincenzo Galasso, Emma Galli, Carla Marchese, Fabio Padovano, Paola Profeta, Anna Rubinchik-Pessach and Ernesto Rezk for helpful comments. Support provided to Winer by the Canada Research Chair Program, the International Center for Economic Research in Turin and the Department of Economics of the University of Turin is gratefully acknowledged. Can Hakyemez, Haizhen Mou and Isilda Shima provided research assistance. Errors and omissions are the responsibility of the authors. 


\begin{abstract}
In this this paper we combine economic factors that have strong trends and political factors that are stationary in a dynamic, empirical model of the evolution of public policy over a very long period in a stable democracy. The role of variation in the intensity of political competition is the substantive focus of our analysis.

The approach we develop is applied to disentangle the contributions of economics and politics to the evolution of public expenditure by the Government of Canada over 130 years, from the origin of the modern state to the end of the 20th century, a long period that has not before been investigated. The degree of political competition emerges robustly as the primary, if not the only important political factor in the long run as well as over shorter horizons.
\end{abstract}

Key Words: political competition, conditional convergence, cointegration, public expenditure, size of government, politics versus economics

JEL Categories: D7, H1, H3, H5 


\section{Introduction}

The purpose of this paper is to develop a method of combining economic and political factors in a dynamic empirical model of the evolution of the relative size of the public sector over a long period in a stable democracy. The role of variation in the intensity of political competition in both long and shorter runs is the substantive focus of our analysis.

Competition in the electoral system has long been regarded as an important mechanism for ensuring that public policy conforms to the wishes of the electorate (Wittman 1995, Breton 1996). It is relied upon heavily in spatial voting models including Coughlin (1992), Hettich and Winer (1999), Adams, Merrill and Grofman (2005) and Schofield and Sened (2006) among others, where competition forces parties to choose platforms that balance the interests of various groups of voters. Following in this tradition, we implement two related views about how the public sector evolves towards a long run equilibrium, and do so in a manner that allows researchers to combine appropriately economic factors that have stochastic trends with measures of political competition and other political factors that are usually stationary.

We begin by defining political convergence as a long run in which the governing party is forced to provide the level of spending demanded by the community, regardless of the state of the political system. ${ }^{1}$ This view is implemented by modelling the long run as a cointegrating relationship among underlying 'economic fundamentals'. While a strong degree of competition is necessary for convergence in this sense, some variation in the degree of competition can be expected to arise even within mature democracies. Allowing for the consequences of this variation, such as the enhancement of political rents which may result in the inflation of government size, leads to a second model of the long run: conditional political convergence which is, simply, convergence to economic

\footnotetext{
1. Convergence of party platforms to the same set of policies is another matter. Competition may or may not lead to convergence in this sense. See Adams, Merrill and Grofman (2005) and Schofield and Sened (2006).
} 
fundamentals conditional on the degree of political competition.

Whether politics, however defined, matters in explanations of public policy depends crucially on the set of conditioning factors included in one's estimating equation. Implementation of the convergence hypothesis has the virtue of requiring the researcher to isolate a cointegrated set of economic factors, to which a stationary measure of political competition can be added in order to decide if political convergence can be rejected in favor of its conditional counterpart. Once the appropriate model of convergence is chosen, additional political factors can then be shown to play a distinct role in the long run evolution of public choices to the extent that they lead to substantial departures from this long run path. The importance of politics (and of economics) can also be explored in relation to the short run, error-correction, process implied by the long run model.

To implement either convergence hypothesis and to estimate the corresponding short run equations, it is necessary to model the long run explicitly. This is also desirable because the path defining long run policy choices is not inherently smooth and could be volatile if the economy was. In that case, deterministic methods of detrending to separate out the shorter run - such as including a lagged dependent variable as a regressor or applying a Hodrick-Prescott filter - could mistakenly attribute too little or too much of the long run variation to the short-run, and thus hide as much as it reveals. ${ }^{2}$ Moreover, and in contrast to deterministic detrending, modelling the long run explicitly allows for interconnections between economic fundamentals and political factors that may be important over shorter horizons, connections which may arise at least because of intertemporal optimization by voters and parties. We shall illustrate how explicit modelling of the long run as opposed to deterministic detrending affects conclusions about the role of political competition.

2. For discussion of this point (applied to macroeconomics, where it has been a key issue), see Canova (1998). 
The approach introduced here, of fitting models of long run political convergence and their corresponding short runs, is applied to study the evolution of the relative size of noninterest, direct spending by the Government of Canada from its origin as a modern state to the end of the 20th century. The application is novel in itself - the data for the study have not before been assembled or exploited, nor has such a long time period been investigated. It is different from, but complementary to, the work of researchers who use international panel data of relatively short duration. Here we extend research on the political economy of fiscal systems by considering a very long horizon within a stable regime, a task for which it is appropriate to use cointegration and error correction modelling. The period covered, from 1870 to 2000 , provides the long span of data (131 years) that is ideal for this kind of statistical work. ${ }^{3}$

While our approach could be applied to any competitive political system, Canada is a particularly interesting case study. First, there are good data for its entire history in which the nature of the majoritarian, parliamentary system has remained essentially unaltered. Second, Canada's unique experience with exchange rate regimes and substantial changes in openness to trade provide a data set that has embedded in it substantial variation in the power of fiscal policy, the importance of external shocks to domestic interests, and the role of balance of payments constraints in determining policy choices. ${ }^{4}$ We can also make use of Canada's relationship with its large U.S. neighbour to define instrumental variables, since U.S. history is not influenced by Canadian events. The Canadian case has been studied before to some extent, though not using the approach nor the long time series we employ. This literature exhibits a lack of consensus on the role of politics

3. Shiller and Perron (1985) and Zhou (2001) suggest that span, without gaps, in a time series is more important than frequency for cointegration analysis.

4. Exports plus imports as a fraction of GNP varies from 0.30 to about 0.88 in the sample. 
in determining the fiscal policy instruments of the Government of Canada. ${ }^{5}$ For example, over the1961-1996 post-war period, Kneebone and McKenzie (1999) use Hodrick-Prescott filters to control for long run factors and find evidence of opportunism and partisanship in the fiscal structure at all levels of government. This stands in contrast to the findings of Serletis and Afxentiou (1998) who find, using annual data for 1926 to 1994, no evidence of any regularity arising between a set of Hodrick-Prescott filtered policy target variables (such as output and unemployment) and a set of similarly filtered government policy instruments (such as government consumption or investment). ${ }^{6}$

The analysis proceeds as follows. In section two we test the two convergence hypotheses as they apply to the evolution of public expenditure of the Government of Canada. Measurement of the degree of political competition is also discussed here. After rejecting political convergence in favour of its conditional counterpart, we use simulation to assess the quantitative importance of variation in the degree of political competition as a source of transitory deviations from the long run. Section three considers whether or not partisanship or political opportunism play a role either in the long or shorter runs. In section four, we compare results based on the cointegration-error correction models of the shorter run with those based on other methods (using a lagged dependent variable and a Hodrick-Prescott trend to model the long run). A concluding section summarizes our results and draws implications for future research. Data sources and an extreme bound analysis concerning the robustness of some key results are presented in an Appendix.

5. Winer (1986) finds evidence of a weak feedback at electoral cycle frequencies from the Gallup poll measure of party popularity to monetary growth under flexible but not under fixed exchange rates since 1945.

6. Kneebone and McKenzie (1999) also consider the provincial sector. Other work on provincial governments also suggest the existence of political influences on fiscal policy: Reid (1998) finds evidence of opportunism, Kneebone and McKenzie (2001) find opportunism and partisanship in components of fiscal policy, and Tellier (2006) shows that political popularity affects the extent to which provincial governments can satisfy ideological preferences. Good data on the provincial sector is available only after the second war, and we do not pursue that application here. 


\section{Long Run Models of Government Size}

The dependent variable for our implementation of the convergence hypotheses and subsequent tests for the role of politics is presented in Figure 1. Here government size is measured by total noninterest expenditure net of intergovernmental grants of the Government of Canada as a fraction of GNP (GSIZE). ${ }^{7}$ We remove interest payments which depend on macroeconomic fluctuations as well as grants to the provinces which lead to changes in size as a result of federal-provincial bargaining. ${ }^{8}$ The difference removing grants makes to our measure of Canadian federal government size is shown as the smaller of the two lines in the figure. We include the share of grants in total federal spending on the right side in some of our estimating equations to reflect the state of federal-provincial competition, but neither this nor use of government size measured gross of grants as the dependent variable affects our substantial conclusions.

[Figure 1 here]

The figure shows that Canada's central government has grown in size relative to GNP more or less constantly over the entire 1870 - 2000 time period. Only since 1992 is there a sign that this upward trend is ending. ${ }^{9}$ The dramatic effect of the two world wars is striking, and we control for the effects of the wars with shift variables as discussed below and indicated in the Appendix.

The history of public expenditure in the figure also shows an increase in variance after the second world war as well as an upward shift in mean. To allow for the rise in variance we use the logarithm of relative government size (LnGSIZE in the tables) as the dependent variable because it

\footnotetext{
7. Exact sources and definitions of all data are given in the Appendix.

8. Further decomposition of spending from 1870 onward is not possible. Data on interest payments from 1867 exists because of the importance attached to the public debt, and early data on federal grants is available as a result of the the Rowell-Sirois royal commission in 1937.
}

9.For a more extensive documentation of this pattern in Canadian public expenditure, see Ferris and Winer (2006b). 
has a standard deviation that is roughly constant before and after the second war ${ }^{10}$. In addition to removing heteroscedasticity, since government size and many of the explanatory variables introduced later are confined to lie between zero and one, the use of logarithms where appropriate (denoted by the prefix Ln) avoids restrictions on the domain of error terms in the estimating equations.

\subsection{Political convergence}

To construct a long run model of government size under either convergence hypothesis, we require a set of variables that both span the very long time period we study and reflect the evolving interests of the electorate. The variables we use are for the most part standard in the empirical literature on growth of government. ${ }^{11}$ We identify the variables of the model in the following paragraphs, illustrate the characteristics of the data in Tables $1 \mathrm{a}$ and $1 \mathrm{~b}$, and summarize the specification of the long run model in Table 2 along with estimation results. For the convenience of the reader in what follows, when referring to variable names we drop the prefix 'Ln' indicating the use of a log transformation.

The starting point is Wagner's Law, the hypothesis that the size of government increases more than in proportion as society grows in scale and complexity. This is interpreted as implying that the elasticity of real per capita income (RYPC) with respect to size is positive. Wagner's Law is enhanced here by including the fraction of the population in agriculture (AGRIC) and the fraction of younger people (YOUNG), in order to represent changes in the structure of the economy and in the strength of interest groups. It is not clear what sign we should expect on these last two variables, and the stability of the coefficients on these and other variables is tested for by estimating most

10. The standard deviation of LnGSIZE is 0.336 over 1870 - 1939 and 0.328 for the period from 1939 to 2001.

11. See, for example, Bird (1970), Kau and Rubin (1981), Borcherding (1985), Mueller (2003), Ferris and West (1996), and Borcherding, Ferris and Garzoni (2004) who review the literature. 
equations over various sub-intervals. ${ }^{12}$

To capture other structural features that may promote more (or less) government involvement, we use immigration rates (IMRATIO) and the openness of the economy through its reliance on foreign trade (OPEN). Immigration has played a major role in Canadian economic and political history, especially before the first war and in the decade following 1945 . The use of openness follows Myrdal (1960,135), Cameron (1978), Rodrik (1998) and others and is appropriate considering the small size of Canada relative to its major trading partner to the South. One argument is that more openness leads to bigger government as voters seek insurance against external shocks. A competing view is that openness restrains government by raising its full cost and by reducing the power of special interests. We shall see that the later view is the one consistent with Canadian data.

Population is not included in the model of convergence even though it is often used to test for scale economies, for several reasons. Often scale economies are not found in studies of government growth, as noted by Borcherding et al (2004). Moreover, population in Canada is not clearly integrated of order one like the other economic factors. ${ }^{13}$ Finally, the log of population is highly correlated (at 0.99 for 1870 -2000) with the log of real per capita income, which is included. ${ }^{14}$

In addition to acknowledging Canada's openness to trade, it is also essential to allow for the unique Canadian experience with flexible and fixed exchange rate regimes. We do so by including an indicator which is equal to 1 when the exchange rate is fixed and zero otherwise (FIXED

12. The use of these variables and not their complement - the degree of urbanization and the percent of the population older than 65 - is dictated by the availability of data for the entire time period. As AGRIC declines and urbanization increases over the entire period, and as YOUNG declines and the percentage of older citizens grows, we might expect greater demands for government services if education and health are largely public responsibilities. On the other hand, if higher education and health is largely private, we would expect the opposite. We are indebted to Keith Acheson for pointing this out.

13. Unlike the other economic variables, the first difference of LnYOUNG fails stationarity at $10 \%$ using 4 lags.

14. Including LnPOP, or alternatively omitting LnPOP and LnAGRIC (which is also highly correlated with real income LnRYPC) results in a similar pattern of results as are presented in Table 2 below. 
EXCHANGE RATES). ${ }^{15}$ The use of the exchange regime indicator is suggested by the well-known Mundell-Fleming class of open economy models in which fiscal policy is a more potent policy instrument in fixed than in flexible exchange rate regimes; on this reasoning, it is sensible to allow for the possibility that fiscal instruments may be employed differently in these two situations.

To complete the long run model we allow for the possibility of a displacement effect after WWII (Peacock and Wiseman 1961); that the country adjusted to the experience of a temporary large spending increase during WWII by acquiescing permanently in the expansion of government size. Figure 1 suggests that this is so, and we include a dummy variable for the post World War Two period (WWIIAftermath) in the cointegrating relationship describing the long run, as well as dummies that control for the temporary shifts in the expenditure process associated with the wars. ${ }^{16}$

The descriptive statistics for the logarithms of the economic factors introduced above are presented in Table 1a, and Table $1 \mathrm{~b}$ presents the descriptive statistics for the political variables to be included in subsequent estimating equations. The political variables are defined and discussed at length later. Here we only note that while government size and the entire set of explanatory economic variables are stationary only in first difference form (with the possible exception of population), the opposite is the case for the political variables, all of which are stationary in levels. ${ }^{17}$ [Tables 1a and $1 \mathrm{~b}$ here]

Since the economic variables are nonstationary in their levels, any regression using these variables alone to explain government size could be spurious. Nevertheless, if the residuals of the estimated equation are stationary, as they turn out to be, we can interpret the results as evidence of an

15. Exchange rates were fixed in the following periods: 1870-1914, 1926-1931, 1939-1951, 1960-1972.

16. See Dudley and Witt (2004) and Legrenzi (2004) for interesting recent evidence on the displacement effect.

17. All unit root tests are based on the AIC criterion and employ the automatic lag length selection in Eviews 5.1. All estimation is conducted using Eviews. 
equilibrium relationship linking them to government size (Engle and Granger, 1987).

The resulting convergence model of long run government size is presented in the first two columns of Table 2. (The third and fourth columns present a test of the conditional convergence hypothesis and is considered later). All estimation is appropriately conducted using least squares.

[Table 2 here]

Column one presents the cointegrating equation based on the simple convergence hypothesis for the entire 1870-2000 time period. The same equation estimated for a shorter period from 1921 for which, in some cases, the data are better is presented in column two. In both cases, the Adjusted DickeyFuller test statistic on the equation residuals falls well inside the modified MacKinnon(1996) critical value for a cointegrating equation with six explanatory variables. ${ }^{18}$ Thus these results do indicate that a cointegrating relationship exists among the key economic variables suggested by the literature on the government growth as amended here to fit the Canadian case.

A look across the first two columns (for the two time periods) indicates a strong degree of consistency in the sign and size of the coefficient estimates. ${ }^{19}$ Of particular interest is the fact that trade openness (LnOPEN) has a negative and highly significant coefficient, since this stands in contrast to results found by Rodrik (1998) and Cameron (1978) based on international panel data. In Canada, greater openness is clearly associated with a smaller rather than a larger government sector, perhaps because openness erodes the power of special interests and makes more difficult the collection of higher tax revenues. These effects appear to have dominated any increased demand for

18. As far as we are aware, there are no critical values for cointegration relationships with breaks occurring at known points. Gregory and Hanson (1996), for example, give approximate critical values for the ADF test of a cointegration equation with a single break arising at an unknown point. Hence despite the high values of the ADF statistics on equation residuals in Table 2, the implied significance may be overstated.

19. The exception is the coefficient of LnYOUNG for which all coefficient estimates are insignificantly different from zero. See the dynamic OLS results in Table 3. 
social assistance to deal with the greater insecurity of a more open economy.

The results also indicate that government size was consistently larger in periods when the exchange rate was flexible rather than fixed. Mundell-Fleming reasoning suggests that fiscal policy should be more effective in altering aggregate demand under fixed rates and this may lead one to expect greater use of the more powerful instrument. However, if variations in size are more effective under fixed rates, then larger changes in size may not be needed to counter effective demand failures. Moreover, a flexible rate tends to free government from the balance of payments constraint on policy choices generally, an interpretation of the negative sign on the fixed exchange rate indicator that is consistent with the negative effect of openness on government size. Finally, we note that as expected, government size appears to be described by a process that shifted permanently upwards in the aftermath of the second war.

While these first results as a whole clearly indicate the presence of a long-run equilibrium with known structural shifts in the intercept, it is possible that innovations in the right hand side variables are correlated. If so, the standard errors of the least squares coefficients in these equations will be inconsistent and may be overstated. To properly assess the significance of the individual coefficients, we follow Saikkonen (1991) and Hamilton (1994) and adjust the equations and their standard errors. This involves re-estimating the models in the first two columns of Table 2 by adding leads and lags of the first differences of all the included right side variables, and then adjusting the standard errors accordingly. ${ }^{20}$ For the entire period the results of this procedure are shown in column one of Table 3. (The other columns concern conditional political convergence, to which we turn immediately below).

20. See Saikkonen (1991) and Hamilton (1994, 608-618). This involves estimating the model in Table 2 with leads and lags of first differences of all I(1) right hand side variables added, with lag and lead length determined by the AIC criterion, and then adjusting the standard errors accordingly. One lead and lag proves to be appropriate. 
The results for the period as a whole now show that conclusions about the size of individual coefficients reached above continue to apply. ${ }^{21}$ The statistical significance of individual coefficients is reduced somewhat, but it proves useful to postpone discussion of this matter until the conditional convergence model is considered.

[Table 3 here]

\subsection{From convergence to conditional convergence: the role of political competition}

Political competition in spatial voting models is central to the result that equilibria consist of policies that cater closely to the interests of voters. The implication is that variations in the degree of competition should matter. A straightforward hypothesis is that imperfect competition enables political and bureaucratic agents to divert public resources to private uses, in part by increasing public expenditure above the long run level determined by the model of convergence. In testing conditional convergence against its unconditional counterpart, then, we investigate whether or not variation in the degree of political competition has increased the growth of government.

To measure the degree of political competition, we rely on the literature on competition and voter turnout where, generally speaking, a less competitive situation is defined as one where competing parties do not have an equal chance of winning, as judged by the ex-post outcome of the election. ${ }^{22}$ The idea is that a large or 'unbalanced' win for the governing party ex post, as measured for example by the deviation from $1 / 2$ in the proportion of votes or seats won, signals ex ante that the election was not competitive in the sense that it could have turned out either way with more or less equal probabilities. A deviation from $1 / 2$ in the vote or seat share of the successful party, and other

21. The exception is for LnYOUNG, whose coefficient changes sign. LnYOUNG was consistently the weakest of our set of potential explanatory variables, never reaching significance at $10 \%$.

22. The work on closeness and turnout includes Filer and Kenny (1980), Cox and Munger (1989), Endersby, Galatas and Rackaway (2002) and Franklin (2004)among many others. 
similar measures, have often been used to explain voter turnout. Such measures are also beginning to be used in the empirical literature on policy choices (Levitt and Poterba 1999, Remmer and Wibbels 2000, Besley, Persson and Sturm 2005, Solé-Ollé 2006).

To measure the degree of political competition, we use the proportion of seats in the House of Commons won by the governing party in each election, labelled SEATS in the tables. (We need not define this variable as a deviation from $1 / 2$ as doing so only affects the size of its coefficient). In the Westminister style parliamentary government of Canada, which has remained essentially unchanged since Confederation in 1867 , it is the number of seats that matters for legislative power, whatever the proportion of the popular vote. ${ }^{23}$ As an additional indicator of the degree of competition we add a zero-one indicator of minority government (MINORITY), which in a parliamentary system may represent periods of particularly intense competition.

Constructing a measure of SEATS won by the governing party is an interesting problem in its own right because of lack of clarity in the nature of political coalitions, even within the stable parliamentary system in Canada. Here we follow Beck (1968) for the period before 1945, when independent legislators were few and far between, and the official Parliamentary website thereafter to define the winning party and whether or not there was a minority party in power. For Beck, independent politicians and small parties before 1945 that always voted with one of the two major parties (either Conservative or Liberal) were categorized as members of that party. ${ }^{24}$ The tests were

\footnotetext{
23. We reran our estimation using the vote share of the winning party (not presented but available on request) and found, as might be expected, broadly similar (but less significant) findings. Although there are a few exceptions in Canadian history, parties that win a majority of SEATS also win a plurality of votes.

24. For example, in the election of September 1926, the Parliamentary website has the Liberal party elected with a minority of 116 of 245 seats. Beck considers the electoral outcome as a Liberal majority of 116 plus 12 independently affiliated members, for a total of 128 . For the combination of Beck and the Parliamentary website, minority governments arise in 1922-26, 1957, 1962-67, 1973-74, and 1979 (15 of 131 years or $11.5 \%$ of the years). The Parliamentary website has minorities in 1922-30,1957, 1962-67, 1973-74, and 1979 (19 or $14.5 \%$ of the years).
} 
rerun for a competing definition based exclusively on the official Canadian parliamentary website with no appreciable change in conclusions.

It is important to note that since SEATS is stationary and government size exhibits a strong trend, we should not expect that variation in the degree of competition will lead to permanent changes in the size of government. Hence by testing conditional convergence against the simpler alternative, we are testing whether or not changes in the degree of competition produce transitory deviations from the long run, and in so doing form part of the stochastic process explaining long run government size. It is in this sense that it is appropriate to add the stationary or $\mathrm{I}(0)$ variable SEATS to a set of variables (in columns one and two of Table 2) that has been shown to be cointegrated.

The introduction of SEATS and of MINORITY into the cointegration relationship results in the new set of findings presented in columns three to six of Table 2, and columns two to four of Table 3 where the Saikkonen adjustment is again applied. Because the ADF statistic on the equation residuals in Table 2 still exceeds the modified MacKinnon critical value (now for seven variables) these results suggest that our measure of competition does form part of the enhanced cointegrating relationship, and that convergence can be rejected in favour of conditional convergence. The coefficient on SEATS remains positive and significant over the whole period in Table 3 after the Saikkonen adjustment is applied, and is significant as well for the sub-periods after 1921 and after 1945, with the coefficient on SEATS falling in size as the sample period is shortened..$^{25}$ This confirms that less competition leads to transitory increases (extending over an electoral period) in the size of the public sector. ${ }^{26}$ Further results concerning the role of competition are provided later.

25. If we do not adjust standard errors using Saikkonen (1991), following instead the Dynamic OLS method of Stock and Watson (1993) where just leads and lags are added, the t-statistics for SEATS in columns 2, 3 and 4 in Table 3 are respectively: $6.34,1.81$ and 1.27. If HAC errors are used, the t's are: $3.94,1.48$ and 1.31 .

26. We also considered the possibility that the effect of competition is nonlinear in SEATS. If we include SEATS squared in addition to SEATS, and re-estimate column three of Table 2 (for the entire period), we find that the terms 
Table 2 also provides information on the role of MINORITY governments over the longer run. In our sample, there were 10 minority governments, most of a few years duration. ${ }^{27}$ Writers such as Weingast, Shepsle and Johnsen (1981), Kontopolous and Perotti (1999) and Persson, Roland and Tabellini (2004) suggest that representative government may suffer from a common pool problem in budgeting - a tendency to over-exploit the general taxpayer in order to deliver specific benefits to particular constituencies. A government in a minority situation can be expected to cater to such demands to a greater extent, since the opposition is in a good position to extract concessions. This reasoning suggests a positive coefficient on MINORITY in an equation for government size. But there is no indication of such a common pool problem in Table 2, where the coefficient on MINORITY is negative though not significant. Nor was MINORITY significant in the models of Table 3 (where the results that include MINORITY are not shown). We shall return to the role of minority government in the analysis of the short run.

\subsection{Further results concerning the role of political competition}

Since the role of political competition is not usually investigated in empirical studies of government size, it is necessary to confirm the importance and robustness of our results. We begin by asking if less competition allows a government to cater to its ideological constituency to a greater extent. For example, do Conservative governments spend less than Liberal ones when competition lessens? ${ }^{28}$ To answer this question, we interact the measure of competition with a one - zero indicator of whether the party in power was center-left (LIBERAL) or center-right under the Conservatives

\footnotetext{
in SEATS are: $2.26 *$ SEATS $-1.46 *(\text { SEATS })^{2}$, with both coefficients insignificant at 10 percent. Ignoring significance, this result implies that the effect of a lessening of competition on government size is concave in SEATS, peaking at SEATS $=0.77$ which is less than its historical maximum of 0.785 . We do not carry this specification forward since the coefficient on the squared term is insignificant, and because doing so adds little to the ability of the equation to predict over the longer term.
}

27. We recall footnote 24 on the definition of a minority here.

28. Solé-Ollé (2006) asks a similar question using Spanish local government data. 
(indicated by 1 - LIBERAL), otherwise using the augmented equations as specified in Table 3 . The results for just the partisan signed measures of SEATS are given in Table 3a along with an F test of whether the coefficients on the two variables are statistically different, in which case we could conclude that a lessening of competition allows ideological preferences to be satisfied to a greater extent.

[Table 3a here]

As the Table clearly indicates, both Conservative and Liberal governments spend more when the degree of competition declines, although Conservatives appear to increase their spending somewhat less than do the Liberals. This difference, however, proves to be insignificant, a story that will continue to hold in the short run models presented later. Apparently it doesn't matter what the ideological stance of the governing party is; they all spend more when competition is reduced and do so to more or less the same extent.

Proceeding with the simpler model in Tables 2 and 3 then, we ask next if the degree of competition is important as well as statistically significant. A useful answer to that question is provided by simulating what would have happened to government size over the long run if political competition had been uniformly intense. To do this, we first generate for the post-war period from 1950 the predicted value of long run government size from the equation in column three of Table 2, shown as the dashed line in Figure 2. (While standard errors in Table 2 may be biased, these are the cointegrating equations that appropriately form the basis for long run predictions as well as for the short run models in the next section.) We then simulate long run size under the hypothesis that the degree of political competition remained uniformly intense, i.e., that SEATS equalled 0.5 over the whole period. This results in the solid line in the figure, showing that greater political competition would have eliminated some of the more dramatic periods of government growth, 
especially during the very large (in terms of the percentage of seats won ) Conservative governments of John Diefenbaker (1957 - 63) and Brian Mulroney (1984 - 93). For specific electoral episodes, it does appear that the effects of imperfect competition are substantial.

[Figure 2 here]

Finally, since the measure of competition is the result of elections, we inquire as to whether SEATS is statistically endogenous in the present context. To do so we use a Hausman test, where the instruments are U.S. growth and U.S. inflation rates and selected lags, and a lagged value of SEATS representing the state of competition in the previous electoral period. ${ }^{29}$ The test indicates that SEATS is endogenous at $1 \%$ over the period from 1876 , and exogenous even at $10 \%$ for the period from 1921. One should note that even if SEATS is endogenous, the estimation in Tables 2 and 3 remains consistent, although in that case it is no longer clear that causality runs only from competition to government size. We also test for the endogeneity of SEATS in the context of the short run models of the change in government size presented below, where it turns out to be exogenous for all samples..$^{30}$

\section{Politics in the Long and (Especially) in the Shorter Run}

The last step in modelling the long run is to determine whether political factors other than the degree of competition and the minority status of a government play a role in creating transitory deviations from the long run. We then turn to the short run.

29. We use the current values and 2 lags as well as the 5th lag of U.S. real growth and U.S. inflation, and the 5 th lag of SEATS.

30. A complementary and supporting analysis using the Johansen $(1991,1995)$ technique, with SEATS included (as potentially endogenous) in the cointegrating relation is presented in the working paper version of this paper (Ferris and Winer, 2006a), and is reported on below. 
To define a set of overtly political factors, we draw on the extensive political business cycle literature, including the work on Canada of Heckelman $(2002,2006)$ and others cited earlier. Virtually all partisan theories of the political business cycle literature, following Hibbs (1977) and many others, start with the presumption that the major party on the left, in Canada the Liberal party, will spend more when in power than will their Conservative rival. We have already tested for the interaction between the degree of competition and partisanship and found this does not add explanatory power. Here we consider whether partisanship alone matters for a given degree of competition. Moreover, should such a partisan effect arise, any diminution (or expansion) of its effect over the tenure of the government in power may depend on the type of party elected, and this we test for using the composite variable DURATION $=$ \{(LIBERAL*ELAPSE) - (1LIBERAL)*ELAPSE $\}$, where ELAPSE is the time (in years) since the last election.

It may be noted that political factors such as those representing partisanship simply need to be present with the right sign in relation to spending to be consistent with the widely held view that parties ideologically to the left tend to spend more. In contrast, many theories of the political cycle (reviewed, for example, by Alesina et al 1997 and Drazen 2001) require an element of surprise or some informational asymmetry between voters and parties for changes in partisanship or other factors to produce real macroeconomic consequences. Here we are interested in the effects of the political system on policy choices, whether or not they have macroeconomic consequences. A test for an effect of political factors on government size is therefore more straightforward than is a test for their effect on macroeconomic aggregates. ${ }^{31}$

31. Haynes and Stone (1990) in their review of the theory of hte political business cycle suggest that partisan and opportunistic effects may not be separable and test for their interdependence. However, our experimentation produced no instances where the interaction was significant. The second major issue pointed to by Haynes and Stone - that political cycles may persist over time - is allowed for in our analysis via the error-correction methodology. 
While several opportunistic or strategic political business cycle theories argue that incumbents use their control to gain votes by manipulating aggregate demand, other work suggests that an increase in spending may occur, with or without the intention of altering demand, because politicians arer trying to signal competency that is private knowledge to them (Rogoff and Sibert $1988)^{32}$, or are forced by competition to undertake actions in the hope that voters will attribute these actions to greater competency (e.g., Shi and Svensson 2006, Mink and de Haan 2005). These strategic theories all require that government size increase in the period leading into an election and therefore predict that the coefficient of ELECTIONYEAR(-1) will be positive. ${ }^{33}$ Moreover, if the intent was to take advantage of voters, the effect may wear off over time, suggesting that ELAPSE itself, independently of DURATION, ought to be included in the equation.

What is the empirical effect of these political factors, which are summarized in Table 1b, when they added to the long run convergence models? It turns out that the answer is given by columns three and four in Table 2, which we have already discussed in the previous section. The absence of any political factors in those columns represents the final stage of an iterative search for cointegration among the enhanced set of economic and political variables. ${ }^{34}$ This search procedure started by adding all political variables discussed above (LIBERAL, DURATION, ELECTIONYEAR(-1), ELAPSE) to the conditional convergent equations of columns (3) and (5). The inability to find evidence of cointegration among this set (as judged by the ADF statistic) then

32. In this case it is the competent politician that increases spending more (or at all), suggesting the effect may be weak. (See Mink and de Haan 2005).

33. Note that because the instrument must be used ahead of the expected effect, changes in government spending must precede the desired consequences, implying that ELECTIONYEAR(-1) or perhaps its 2 nd or 3rd lag is more appropriate than the current value. Experimentation with all these forms produced similar results.

34. In the tests we follow the Beck/Parliamentary website measure of winning majorities and whether there was a minority. The tests were rerun for a competing definition, based exclusively on the official Canadian parliamentary website data, with no appreciable change in results. 
led to the elimination of the least significant variableand retesting. Testing continued in this manner until the model was again represented by columns three and five and cointegration was again established. Such a finding implies that political variables representing the timing of elections and the switching of power between partisan opposites do not enter the cointegrating relation.

Such a result might already have been expected on the basis of the differences in the order of integration of government size and of the political factors although, as indicated by Table 2 and the simulations in Figure 2, variation in the degree of political competition does play a (transitory) role in the model of conditional convergence. We conclude that the conditional convergence models in Table 2 provide a reasonable long run relationship on which we can base an error correction model of short run adjustment, and that we can use the lagged residuals from the equations in Table 2 as the error correction terms to be used in the models of short run adjustment.

\subsection{The role of politics in the shorter run}

As suggested above, it would be less surprising to find that political factors do matter in the short run adjustment process. Indeed, the power of partisan and opportunistic political theories of the political business cycle is their implicit reliance on the strategic use of short run variation in spending (and other instruments) to influence voting behavior.

The results of our test for the presence of political factors in the shorter run adjustment process implied by the conditional convergence model are presented in the error correction models of Tables $4 \mathrm{a}$ and $4 \mathrm{~b}$. To reinforce these findings, the Appendix presents an extreme bounds test of the interpretation that we place on these findings. Table 4a presents results where only contemporaneous first differences are used in formulating the error correction model in the EngleGranger tradition. Table $4 \mathrm{~b}$ expands that model to capture more of the intertemporal adjustment process through the use of three lagged values of the first differences. 
[Table 4a here]

Columns one and two of Table 4a present the error correction models that correspond to the unconditional political convergence hypothesis implemented in the corresponding columns of Table 2. None of the political variables are included here. The last two columns correspond to the conditional convergence models in Table 2 . All equations include dummy variables to allow for breaks at the time intervals associated with the breaks found in the long run. In addition, effective representation of the wars must now allow for both the rapid increase in spending during a war and the subsequent rapid decrease thereafter. This requires the addition of the dummy variables WWIAfter and WW2After. We also include a dummy variable for periods when the exchange rate was fixed, as the exchange regime may influence the choice of fiscal policy instrument in the short run as well as in the long run, and a variable representing changes in the scale of federal transfer payments to other levels of government as a share of non-interest federal spending net of grants, D(LnGRANT_SHARE), which a Hausman test indicates is exogenous in the present context. ${ }^{35}$ In keeping with our concern with the role of political competition, this last variable can be regarded as an ex post measure of intergovernmental competition, where success in provincial capitals is often measured by how large an increase in grants has been recently negotiated. From the federal government's perspective, short run changes in the size of federal grants could well speed up or hold back competing federal programs and so influence the ability of the federal government to exercise short run discretionary changes in policy.

35. Hausman tests to check for the endogeneity of D(LnGRANT_SHARE), and also of SEATS, in the error correction formulation employ the equations in columns 3 and 4 of Table 4 b below as a base. Instruments used are current values and lags of U.S. growth and inflation, as before, as well as the 4th and 5th lag of D(LnGRANT_SHARE), representing the previous electoral period, and the 5th lag of SEATS when that variable is considered. When D(LnGRANT_SHARE) alone is considered, the Hausman test indicates it is exogenous over the periods from 1876 and from 1922. When both it and SEATS are considered jointly, they are both found to be exogenous over both periods. 
The resulting relationships work well, explaining between sixty and seventy percent of the short run variation in government size over the various time periods considered.$^{36} \mathrm{In}$ each, the error correction term is negative as expected (for convergence to the long run to occur) and significant, and the coefficient estimates are broadly similar across equations. The size of the error correction coefficients implies that deviations from long run size are corrected in about three to five years.

One of the most interesting features of the error correction models is that the coefficient estimate on the contemporaneous change in income is significantly negative in all equations and hence opposite in sign to the long run coefficient estimates in Tables 2 and 3 . This provides strong evidence of a counter cyclical role for government spending. Hence the data is consistent both with Keynesian counter cyclical fiscal expenditure policy in the short run and with Wagner's Law in the the long run. Such a result illustrates nicely how the co-presence of these two aspects of political behavior, implying opposing relationships of public expenditure to real income over different time horizons, can easily be co-mingled in different tests that do not distinguish long from short run. ${ }^{37}$

Another feature of the error correction equations is that increases in the share of intergovernmental transfers (out of federal spending) are clearly associated with declines in the size of the federal government relative to GNP. Our guess is that these changes reflect the political strength of the federal government versus the provinces and so capture the negative effect of greater intergovernmental competition on federal government size.

36. When the equations were rerun over the 1945 to 2000 time period, the error correction term became insignificant, suggesting that short run adjustment was distinctly different in the later time period. For an interpretation of what was happening in the post WWII time period, see Ferris and Winer (2003).

37. In addition, note that although changes in government size show no significant response to periods of fixed exchange rates, the estimated coefficient changes from negative (in the long run model of Tables 2 and 3 ) to positive in Table 4a, suggesting as well that government size was adjusted more often in response to transitory economic events in periods of fixed (rather than flexible) exchange rates. As might be expected with respect to our other hypotheses, structural features of the economy which matter most for the long run show up in varying degrees of importance in the short run. 
Columns three and four of Table $4 \mathrm{a}$ are the error correction versions of the conditional convergence model. Here we used the same general to specific methodology as before to reveal significant political variables. As indicated by their absence from the table, in no case was a political variable other than SEATS found to be significant. Note that rather than presenting all of the insignificant coefficients here, we show only the equations with SEATS and append an Extreme Bounds Analysis based on adding all of the political variables into the error correction version of the conditional convergence model in column three of Table 2. This is given in the Appendix to verify the significance of SEATS and the insignificance of other political variables.

Thus neither the time period leading into an election (ELECTIONYEAR(-1)), nor the time since an election (ELAPSE), nor the partisan nature of government by itself (LIBERAL), nor the duration of partisan power (DURATION), nor periods of minority government (MINORITY) have any consistent effect on short run variations in government size. None of the partisan or opportunistic political variables are significantly different from zero. However, the data does support the hypothesis that the degree of political competition matters for explaining short run variations in government size. The error correction models thus produce evidence consistent with political competition driving convergence in the short as well as in the longer run.

\subsection{Other formulations of the short run model}

Table $4 \mathrm{~b}$ presents a fuller formulation of the short run adjustment process using three lagged first differences of the economic variables. Just as in Table 4a, but with much less evidence of serial correlation, the only political factor that remains significant in the short run is SEATS. Other results remain essentially unchanged. Again, the role of political competition appears to be substantial..$^{38}$

\footnotetext{
38. Using estimates in Table $4 \mathrm{~b}$ for the whole sample, a victory on the scale of the 1958 Conservative landslide would result in an increase in real growth of $5.3 \%$, and a one standard deviation increase in SEATS leads to an increase in the growth of GSIZE of $2.5 \%$.
} 
[Table $4 \mathrm{~b}$ and Table $4 \mathrm{~b}(\mathrm{I})$ here]

We note also that in the working paper version of this study (Ferris and Winer, 2006a), where a supporting analysis using the Johansen method is presented, with SEATS treated as part of the cointegrating relation, impulse responses indicate that a shock to SEATS has a substantial cumulative effect on government size relative to the effect of size on SEATS.

The supplement to Table $4 \mathrm{~b}$, Table $4 \mathrm{~b}(\mathrm{I})$, which is analogous to Table $3 \mathrm{a}$, investigates the question of whether a lessening of competition allows a governing party to satisfy ideological preferences at least for an electoral period. Again the answer is no. As in the long run, the results show that both parties increase spending when competition declines, and although Conservatives appear to increase spending to a lesser extent than do Liberals, statistically there is no difference between the parties.

\section{Alternative Dynamic Models and Deterministic Detrending}

The error correction models presented above are based on the premise that the determinants of long and shorter run changes in public policy are intertwined and that the long run must be modelled explicitly in order to expose appropriately shorter run behavior. Many dynamic political economy models do not explicitly model the long run, using instead a lagged dependent variable or a HodrickPrescott filter to deal with the dynamic nature of the short run process under investigation. In this section we compare the cointegration - error correction approach with formulations of these types.

Table 5 presents selected aspects of the results of estimating an error-correction, cointegration model (in column one) along with five alternative dynamic formulations (in columns two through six), for the various sample periods indicated. In all cases, only the definition of the dependent variable and of the economic factors, as well as estimation results for the lagged 
dependent variable or the Hodrick-Prescott (HP) trend and the political factors are recorded. ${ }^{39} \mathrm{All}$ equations use the same basic set of variables. ${ }^{40}$

[Table 5 here]

The alternatives to the error correction model in column one are as follows: in column 2, LnGSIZE is modelled with its lag and economic factors in log-level form, as well as with the common set of political factors which are entered the same way in all equations; in column 3, first differences are used: $\mathrm{D}(\mathrm{LnGSIZE})$ is modelled using its lag and the first difference in logs of the economic factors, so that this equation differs from the error correction model in column one only by the replacement of the error-correction term with $\mathrm{D}(\operatorname{LnGSIZE})_{\mathrm{t}-1}$; in column 4 , the HodrickPrescott cyclical component of LnGSIZE is modelled using its lag and the economic factors in first difference form; in column 5, the same specification as in column 4 is employed except that the economic variables are also in HPcycle form; and finally, in column 6, LnGSIZE itself is modelled using its HP trend to represent the long run, and by the first differences of logs of the economic factors and the common set of political factors to represent the short run.

In briefly discussing the results, we focus on the political variables over the longer period from 1871. In the error-correction model and in the estimated models of columns two and three, only SEATS matters. In columns four and six, none of the political factors are significant, while in column five, only MINORITY is significant. It is important to note that in the equations using HP detrending, in columns four through six, the coefficient on SEATS is negative in contrast to the error correction results in column one and the models in columns two and three. This also holds for the

39. The equations that use HP detrending are estimated over periods that remove the beginning and end of the sample as these are affected by the mechanics of the detrending procedure. Estimating the other equations over the shorter period indicates that comparisons across alternative formulations are not affected by the shorter time period. We also note that use of two lags of the dependent variable as regressors does not alter the substantive results.

40. To improve comparability across equations, all t-statistics are of the Newey-West (HAC) type. 
shorter time period as well. (For the shorter time period in column six, the negative coefficient on SEATS is also significant.)

That the results using the Hodrick-Prescott filter are so different is not surprising. A key reason for the difference is evident in Figure 4, where the HP trend for LnGSIZE is compared to the prediction that arises from our preferred cointegration model in column three of Table 2. By inspection of that figure, and from the table of descriptive statistics presented below, it can be seen that the long run based on the cointegration model has higher frequency elements in it and that these are skewed differently as well. ${ }^{41}$ This difference carries over into the models of Table 5 through the the various methods used to control for the long run evolution of government size.

[Figure 4 here]

The lesson that emerges from this comparative analysis is that it matters how the data are detrended and, more generally, how the interaction between long and shorter runs is modelled. While deterministic detrending or the use of lags to get at short run behavior may be convenient, our experiments suggest that explicit modelling of the long run is to be preferred.

\section{Conclusions}

In this paper we develop a methodology for studying empirically the evolution of public policy over a long period within a stable democracy. The approach is consistent with the logic of spatial voting models and begins by testing two long run hypotheses: political convergence to basic economic factors versus its conditional counterpart. It does so in a manner that allows economic factors which have trends to be combined conveniently with a measure of the degree of political competition that

41. The table also shows that what is evident in the figure is not simply a product of including the war years in the sample 
is stationary. Implementation of the convergence hypotheses requires the careful choice of a set of cointegrated economic factors that serve along with the degree of competition as controlling variables in the subsequent investigation of the role of other political factors over both longer and

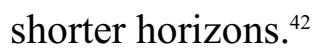

The analysis is based not only on the need to cope with the different orders of integration of economic and political factors but also on the premise that long and shorter run changes in public policy are intertwined. Hence the models we have estimated distinguish between changes in policy that arise over the longer run - which, we have argued, needs to be modelled explicitly - from those policy actions that arise over, or in relation to, the cycle. Studying the short run most likely requires more than simply subtracting out a trend: an encompassing empirical approach is required to disentangle and interpret the connections that link political decision-making over different horizons.

We have applied the approach to model the relative size of non-interest, direct spending by the Government of Canada over a period that extends almost from the founding of the modern state to the beginning of the 20th century, a span of about 130 years. This long time series is ideal for the present investigation and, to the best of our knowledge, has not been studied before. Our results indicate that neither the timing of political events, the partisan nature of the governing party, nor the duration of partisan power prevent the convergence of government size on its long run size as defined by economic interests, conditional on the degree of political competition. Nor does there seem to be any evidence that the timing or partisan nature of party politics matter in relation to cyclical variations about that long run. Of the political factors we have considered, only the degree

\footnotetext{
42. We recall that in this investigation, a change in perspective from that used to uncover the role of politics in creating political business cycles is required. Unlike the test of rational partisanship in business cycle studies, for example, where surprise spending is important, surprise itself is not needed for evidence of a partisanship effect on government size.
} 
of political competition in both the short and the long run clearly affects the convergence of public expenditure to its long run path defined by economic 'fundamentals'. ${ }^{43}$ In general, it appears that less competition leads temporarily to larger government (relative to its long run path).

The results as a whole also show that how the dynamic character of a policy process is modelled matters a great deal. Deterministic detrending to get at the political factors that are important for the evolution of public policy over the shorter run does not lead to the same conclusion as does modelling the long run explicitly. In our view, explicit modelling of the long run is better. This lesson likely applies to many aspects of the study of public policy.

Finally, the persistent significance and quantitative importance of the degree of political competition in Canada suggests that more attention should be given in empirical research to the measurement and role of competition in forcing the matching of policy choices with underlying characteristics of the electorate. ${ }^{44}$ While other political environments will differ and the form of competition change, the general nature of our findings suggests that the role political competition has received insufficient attention and that there is a potential payoff to its more extensive empirical study both within Canada and elsewhere.

43. There is also some weak evidence that periods of minority government are more intensely competitive in this respect.

44. With respect to measurement, future work might consider a definition of competition based on the number of marginal political constituencies or votes, following Mayhew (1974) and others. The considerable task is to define explicitly what 'marginal' means and this is certainly a subject for another paper. With respect to policy outputs, one might also model the composition of spending, though a long time series such as used in this paper is not then available. 


\section{Appendix: Data Sources and Extreme Bounds Analysis}

\section{A. The Data}

The data come from several sources: Urquhart, M.C., Canadian Historical Statistics and Gross National Product, $1870-$ 1926, McGill-Queen's University Press for the structural variables in the earliest time period (1870 through 1921); Cansim, the statistical database maintained by Statistics Canada, for these variables in the later time period (1921-2001); Gillespie's (1991) reworking of the Federal public accounts from 1870 to 1990, updated by Ferris and Winer (2003); and Beck (1968), and the official web site of Parliament www.parl.gc.ca for election data. More precise definitions and sources are given below.

\section{Economic Variables and Data Sources:}

AGRIC = proportion of the labour force in agriculture. 1871-1926: Urquhart, (1993), 24-55; 1926-1995 Cansim series D3 1251 divided by D31252; 1996-2001: Cansim II series V2710106 divided by V2710104.

$\mathbf{D}=$ first difference operator

EXPORTS and IMPORTS = exports and imports. 1870-1926, Urquhart, (1993) Table 1.4; 1927-1960, Leacy, et al, 1983, Series G383, 384; 1961-2001: CANSIM series D14833 \& D14836.

OPEN = openness of the economy. Calculated as: (EXPORTS + IMPORTS) / GNP.

GNP = gross national product in current dollars. 1870-1926: Urquhart (1993), pp. 24-25 (in millions); 1927-1938: Leacy et al (1983), Series E12, p.130; 1939-1960 Canadian Economic Observer, Historical Statistical Supplement 1986, Statistics Canada Catalogue 11-210 Table 1.4. CANSIM D11073= GNP at market prices. 1961-2001 Cansim I D16466 = Cansim II V499724 (aggregated from quarterly data).

GOV = total federal government expenditure net of interest payments.1870-1989: Gillespie (1991), pp.284-286; 1990-1996: Public Accounts of Canada 1996-97: 1997-2000: Federal Government Public Accounts, Table 3 Budgetary Revenues Department of Finance web site, September 2001. To this we add the return on government investment (ROI) originally subtracted by Gillespie for his own purposes. Expenditure is net of interest paid to the private sector. Data on ROI: 1870 to 1915: Public Accounts 1917 p.64; 1915-1967: Dominion Government Revenue and Expenditure: Details of Adjustments 1915-1967 Table W-1; 1916-17 to 1966-67: Securing Economic Renewal - The Fiscal Plan, Feb 10, 1988, Table XI; 1987-88 to 1996-97: Public Accounts 1996, Table 2.2. Interest on the Debt (ID) was subtracted out (with adjustment for interest paid to the Bank of Canada (BCI) ultimately returned to the government). Data on ID: 1870-1926: Historical Statistics of Canada, Series H19-34: Federal Government budgetary expenditures, classified by function, 1867-1975; 1926-1995: Cansim D11166. 1996-2000: Cansim D18445. Finally, data for BCI: copied by hand from the Annual Reports of The Bank of Canada, Statement of Income and Expense, Annually, 1935-2000. Net Income paid to the Receiver General (for the Consolidated Revenue Acct). Note: all government data is converted from fiscal to calendar years, and allows for a change in the definition of the fiscal year in 1906/07, as described in Gillespie (1991, Appendix C).

GSIZE = non-interest federal government, direct public expenditure, calculated as: (GOV- GRANTS) / (GNP)

GRANTS = transfers to provinces and local governments; 1870 - 1912: From Rowell-Sirois Commission, "Subsidies and Grants Paid to Provinces Since Confederation", Table II; 1913-1935: From Rowell-Sirois Commission, "DominionProvincial Subsidies and Grants", Statistical Appendix, p. 186; 1926 - 2001: Cansim label D11164 and D11165.

GRANT_SHARE $=$ GRANTS / GOV

IMMIG = immigration numbers. 1868 - 1953: Firestone (1958), Table 83, Population, Families, Births, Deaths; Updated by Cansim D27 (1955 to 1996). Cansim Sum of X100615 (Females) plus X100614 (Men) for 1954;1997-2001, Cansim D27 (sum of quarters).

IMMRATIO = IMMIG/POP. 
IPIUS = index of Industrial Production for the United States. 1870-1929: Table A15. NBER, Nutter; 1930-1970, Table A16. (BEA) Bureau of Economic Analysis;1971-1995: Cansim D360048 (1987=100);1996-2000, U.S. Department of Commerce, Business Cycle Indicators, Index of Industrial Production 1992=100.

$\mathbf{L n}=$ the $\log$ operator.

YOUNG = percentage of the population below 17.1870-1920 Leacey et al (1983). Interpolated from Census figures Table A28- 45 sum of columns 29, 30, 31, and 32 all divided by 28 (adjusted to make 1921 the same); 1921-2001 Cansim C892547.

$\mathbf{P}=$ GNP deflator before 1927 and GDP deflator after $(1986=100) .1870-1926:$ Urquhart, (1993), 24-25;1927-1995 (1986=100): Cansim data label D14476; 1996-2001 Cansim D140668. All indexes converted to $1986=100$ basis.

POP = Canadian population. 1870-1926: Urquhart, (1993), 24-25; 1927 - 1995: CANSIM data label D31248; 1995 2001: Cansim D1 (average of four quarters).

RGNP $=$ real GNP $=$ GNP $/ \mathrm{P}$

$\mathbf{R Y P C}=$ real income per capita $=\mathrm{GNP} /(\mathrm{P} * \mathrm{POP})$

WWI $=1$ for $1914-1919 ;=0$ otherwise. WW 1 after $=1$ for 1919-1921; $=0$ otherwise.

WWII $=1 / 2$ in 1940,1 for $1941-1945,1 / 2$ in $1946 ;=0$ otherwise. WW2after $=1$ for $1946-1949 ;=0$ otherwise.

WWIIAftermath $=1$ from 1946 onward; $=0$ otherwise.

The WW 1 and WW2 dummies apply to spending relative to GNP, and take into account the actual result of mobilization and demobilization as revealed by LnGSIZE in each of the world wars.

\section{Political Variables and Data Sources:}

The effective dating by year of each election was chosen to reflect the first year that each governing party was in power, allowing for a period of about one quarter for the new government to settle in office and begin to alter previously established spending patterns (if it so chooses). If an election was held between January and June 30, the election was assigned to the actual calender year in which the election occurred. If the election was held between July and December, it was attributed to the following year. There are only two elections in July in the sample period, little is accomplished in the summer, and elections in the fall or early winter do not leave enough time for a new government to alter spending programs before years end - the effective date of these late in the year elections is assigned to the following calendar year.

We note that data concerning SEATS, MINORITY and VOTES differs from that on the official parliamentary web site for the period before 1945. We follow Beck (1968) who makes a sensible decisions about which small parties always supported the government, and hence which effectively should be counted as part of it. On this basis:

ELAPSE $=$ the number of years since the last election.

ELECTIONYEAR $=1$ if an election year; $=0$ otherwise.

LIBERAL $=1$ if governing party was the Liberal Party; = 0 if any other (more conservative) party.

MINORITY $=1$ if the governing party was part of a minority government; $=0$ otherwise

SEATS $=$ percentage of the seats won (or effectively controlled) by the governing party.

VOTES = percentage of the popular vote won by the governing party.

\section{Data Sources for political variables:}

Beck, Murray, J. (1968). Pendulum of Power. Scarborough: Prentice Hall of Canada

Campbell, Colin (1977). Canadian Political Facts 1945-1976. Toronto: Methuen

Canadian Parliamentary Guide. Various years (1997, 2002).

Elections Canada (2001). Thirty Seventh General Election. Ottawa.

Scarrow, Howard A.(1962). Canada Votes: A Handbook of Federal and Provincial Election Data. Hauser Printing. Official web site of the Parliament of Canada: www.parl.gc.ca ((recording data provided by the Chief Electoral Officer) 
B. Extreme Bounds Analysis

Extreme Bound Analysis Concerning Political Factors
Based on Table 4a, column 3
(Absolute value of Newey-West HAC t-statistics in brackets)

$\begin{array}{lccccc} & \text { Seats } & \text { Minority } & \text { Electionyear(-1) } & \text { Duration } & \text { Liberal } \\ \text { Eq0 } & 0.296^{*} & & & & \\ \text { Eq1 } & 0.378^{* *} & 0.033 & & & \\ \text { Eq2 } & 0.296^{* *} & & 0.003 & & \\ \text { Eq3 } & 0.297^{* *} & & & 0.001 & 0.014 \\ \text { Eq4 } & 0.305^{* *} & & & & \\ \text { Eq5 } & 0.377^{* *} & 0.033 & 0.002 & & \\ \text { Eq6 } & 0.379^{* *} & 0.033 & & 0.0008 & 0.015 \\ \text { Eq7 } & 0.389^{* *} & 0.034 & & & \\ \text { Eq8 } & 0.297^{* *} & & 0.003 & 0.0008 & 0.014 \\ \text { Eq9 } & 0.305^{* *} & & 0.002 & & 0.024 \\ \text { Eq10 } & 0.308^{* *} & & & -0.003 & 0.024 \\ \text { Eq11 } & 0.378^{* *} & 0.033 & 0.002 & 0.0008 & 0.026 \\ \text { Eq12 } & 0.308^{* *} & & 0.001 & -0.003 & 0.015 \\ \text { Eq13 } & 0.394^{* *} & 0.035 & & -0.003 & 0.026 \\ \text { Eq14 } & 0.389^{* *} & 0.034 & 0.0006 & & \\ \text { Eq15 } & 0.395^{* *} & 0.035 & -0.0004 & -0.003 & 0.02 \\ & & & & & 0.006\end{array}$

$\underline{\text { Extreme Bounds Analysis Table }}$

\begin{tabular}{|c|c|c|c|c|c|}
\hline Variable Name & $\begin{array}{l}\text { Lower } \\
\text { Bound }\end{array}$ & $\begin{array}{l}\text { Upper } \\
\text { Bound }\end{array}$ & $\%$ Sign. at $1 \%$ & $\%$ Sign at $5 \%$ & $\begin{array}{l}\text { Standard } \\
\text { Deviation }\end{array}$ \\
\hline Seats & 0.296 & 0.395 & $6.25 \%$ & $100 \%$ & 0.043 \\
\hline Minority & 0.033 & 0.035 & 0 & 0 & 0.001 \\
\hline Electionyear(-1) & 0.001 & 0.003 & 0 & 0 & 0.001 \\
\hline Duration & -0.004 & 0.001 & 0 & 0 & 0.003 \\
\hline Liberal & 0.014 & 0.026 & 0 & 0 & 0.006 \\
\hline
\end{tabular}

Notes: ${ }^{*}(* *)[* *]$ significant at $1 \%(5 \%)(10 \%)$. 
Figure 1

Central Government Size Relative to GNP, Canada 1870 - 2000

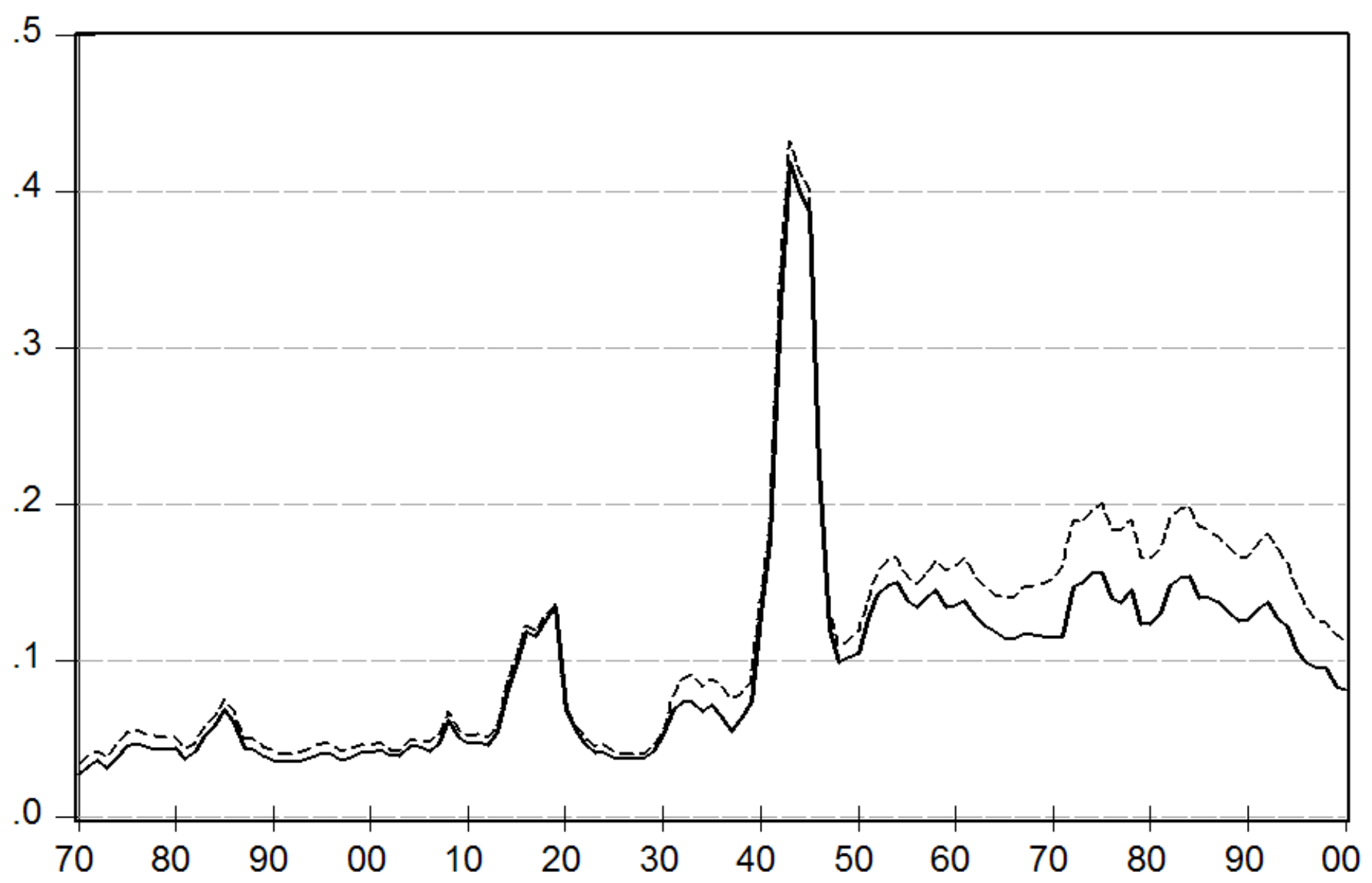

Federal Government Noninterest Expenditure Net of Grants/GN P ----- Federal Government Noninterest Expenditure/GN P 
Table 1a

Descriptive Statistics for Government Size and Various Economic Factors, 1870 - 2000

\begin{tabular}{|c|c|c|c|c|c|c|c|c|}
\hline & GSIZE & LnGSIZE & LnRYPC & LnAGRIC L & LEIMRATIO & LnYOUNG & LnOPEN & LnPOP \\
\hline Mean & 0.097 & -2.52 & 8.67 & -1.64 & -4.9 & 3.59 & -0.83 & 9.29 \\
\hline Median & 0.082 & -2.5 & 8.47 & -1.09 & -4.9 & 3.65 & -0.87 & 9.29 \\
\hline Maximum & 0.419 & -0.87 & 10.1 & -0.54 & -2.95 & 3.88 & -0.13 & 10.33 \\
\hline Minimum & 0.028 & -3.57 & 7.39 & -3.61 & -7.28 & 3.14 & -1.18 & 8.2 \\
\hline Std. Dev. & 0.068 & 0.61 & 0.81 & 1.02 & 0.89 & 0.19 & 0.22 & 0.67 \\
\hline Skewness & 2.382 & 0.29 & 0.16 & -0.68 & -0.47 & -0.84 & 0.99 & -0.01 \\
\hline ADF Levels & -2.31 & -2.04 & -0.1 & 2.37 & $-3.25 * *$ & 1.41 & -0.48 & -0.64 \\
\hline $\begin{array}{l}\text { ADF 1st } \\
\text { Difference }\end{array}$ & $-8.66^{*}$ & $-6.97 *$ & $-5.47 *$ & $\begin{array}{c}-1.87 \\
(-8.69 * \text { with } \\
\text { time trend) }\end{array}$ & $-5.95 *$ & $-3.78^{*}$ & $-5.89 *$ & $\begin{array}{c}-3.01 * * \\
(-2.50 \text { with } \\
4 \text { lags })\end{array}$ \\
\hline
\end{tabular}

Notes: $*(* *)[* *]=$ significant at one (five) $[$ ten $]$ percent.

ADF $=$ Adjusted Dickey-Fuller Statistic, using AIC criterion with a constant and automatic lag selection in Eviews 5.1. ADF critical value at $1 \%=-3.48$; at $5 \%=-2.88$; at 10\% $=-2.58$ (MacKinnon, 1996).

$\mathbf{L n}=$ denotes the natural log of the indicated variable. See the Appendix for exact definitions of variables.

GSIZE = gross expenditure of the Government of Canada less net interest paid to the private sector and less grants to lower levels of government / GNP.

Table 1b

Descriptive Statistics for Political Variables, 1870 - 2000

$\begin{array}{lcccccc} & \text { ELECTIONYEAR } & \text { ELAPSE } & \text { LIBERAL } & \text { MINORITY } & \text { SEATS } & \text { DURATION } \\ \text { Mean } & 0.267 & 1.649 & 0.588 & 0.115 & 0.601 & 0.168 \\ \text { Median } & 0 & 2 & 1 & 0 & 0.586 & 0 \\ \text { Maximum } & 1 & 5 & 1 & 1 & 0.785 & 4 \\ \text { Minimum } & 0 & 0 & 0 & 0 & 0.413 & -5 \\ \text { Std. Dev. } & 0.444 & 1.37 & 0.494 & 0.32 & 0.087 & 2.142 \\ \text { ADF Levels } & -2.99 * * & & & & & \\ & \left(-5.92^{*} \text { with } 4\right. & -10.25^{*} & -4.21^{*} & -5.45^{*} & -3.84^{*} & -5.53^{*}\end{array}$

Notes: $*(* *)=$ significant at one (five) percent.

DURATION $=\{($ LIBERAL*ELAPSE $)-(1-$ LIBERAL $) * E L A P S E ~\}$.

See also notes to Table 1a. 
Table 2

Long Run Models of Government Size: 1870 - 2000 and 1921 - 2000

(Absolute values of t-statistics in brackets) \#

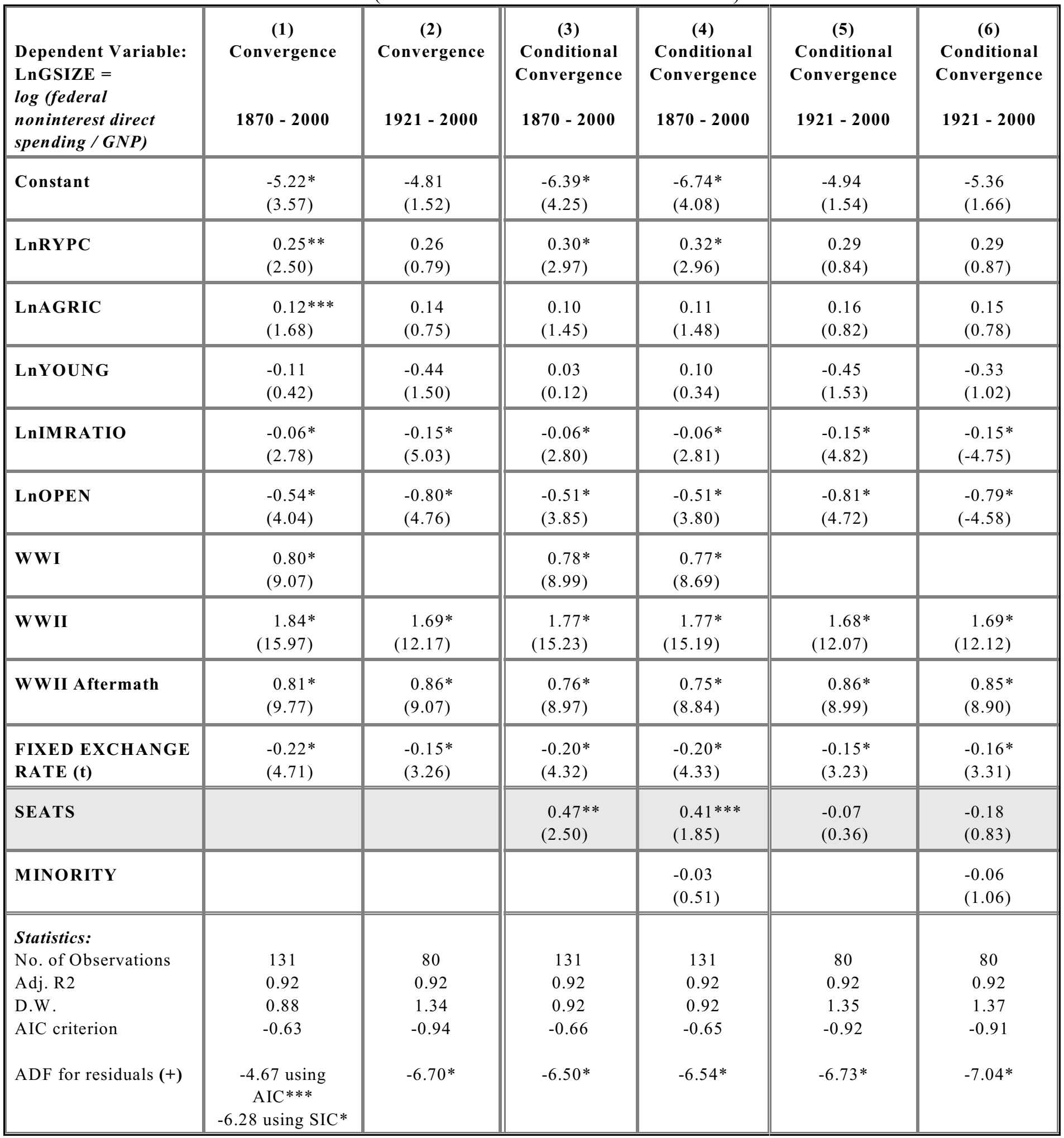

Notes: ${ }^{* * *}\left[{ }^{* * *}\right]$ significantly different from zero at $1(5)[10] \%$.

\#: The t-statistics in these regressions are inconsistent because of correlations arising among the random components of the I(1) variables and hence are unreliable for use as significance tests. See accompanying Table 3 for Saikkonen's adjustment.

t: Periods when exchange rates were fixed (or 'heavily' managed) in Canada are: 1870-1914, 1926-1931, 1939-1951, and 1960-1972. +: MacKinnon (1996) critical values: at $1 \%$ for 6 varbs $=-5 . .45$ using $\mathrm{N}=131$; with 7 varbs $=-5.74$. AIC and SIC criterion based on automatic lag selection in EViews 5.1. In columns (2) to (4), AIC and SIC criteria produce almost the same values. 
Table 3

Saikkonen Supplement to Table 2: Long Run Models of Government Size

Various Periods, 1872 - 1999

(Absolute value of Saikkonen adjusted t-statistics in brackets) \#

\begin{tabular}{|c|c|c|c|c|}
\hline $\begin{array}{l}\text { Dependent Variable: } \\
\text { LnGSIZE }\end{array}$ & $\begin{array}{c}(\mathbf{1}) \\
\text { Convergence } \\
\text { See Table 2, Col. } 1 \\
\mathbf{1 8 7 2} \text { - } 1999\end{array}$ & $\begin{array}{c}(\mathbf{2}) \\
\text { Conditional } \\
\text { Convergence } \\
\text { See Table 2, Col. } 3 \\
\mathbf{1 8 7 2}-\mathbf{1 9 9 9}\end{array}$ & $\begin{array}{c}(\mathbf{3}) \\
\text { Conditional } \\
\text { Convergence } \\
\text { See Table 2, Col. } 5 \\
\mathbf{1 9 2 1}-\mathbf{1 9 9 9}\end{array}$ & $\begin{array}{c}(4) \\
\text { Conditional } \\
\text { Convergence } \\
1945 \text { - } 1999\end{array}$ \\
\hline Constant & $\begin{array}{l}-7.19^{* *} \\
(2.10)\end{array}$ & $\begin{array}{l}-11.01 * \\
(5.86)\end{array}$ & $\begin{array}{l}-12.55^{*} \\
(2.95)\end{array}$ & $\begin{array}{l}-19.26 \\
(1.50)\end{array}$ \\
\hline LnRYPC & $\begin{array}{c}0.33 \\
(1.61)\end{array}$ & $\begin{array}{l}0.60^{*} \\
(5.18)\end{array}$ & $\begin{array}{l}0.85^{* * *} \\
(1.94)\end{array}$ & $\begin{array}{c}1.74 \\
(1.26)\end{array}$ \\
\hline LnAGRIC & $\begin{array}{c}0.11 \\
(0.55)\end{array}$ & $\begin{array}{l}0.29^{*} \\
(2.75)\end{array}$ & $\begin{array}{l}0.40^{* * *} \\
(1.68)\end{array}$ & $\begin{array}{c}1.00 \\
(1.50)\end{array}$ \\
\hline LnYOUNG & $\begin{array}{c}0.25 \\
(0.38)\end{array}$ & $\begin{array}{c}0.53 \\
(1.58)\end{array}$ & $\begin{array}{c}0.37 \\
(0.87)\end{array}$ & $\begin{array}{c}0.73 \\
(1.18)\end{array}$ \\
\hline LnIMRATIO & $\begin{array}{c}-0.09 * * * \\
(1.74)\end{array}$ & $\begin{array}{l}-0.06 * * \\
(2.34)\end{array}$ & $\begin{array}{l}-0.16^{*} \\
(4.21)\end{array}$ & $\begin{array}{l}-0.08 \\
(1.42)\end{array}$ \\
\hline LnOPEN & $\begin{array}{l}-0.49 \\
(1.55)\end{array}$ & $\begin{array}{r}-0.35 * * \\
(2.16)\end{array}$ & $\begin{array}{l}-0.54 * * \\
(2.59)\end{array}$ & $\begin{array}{c}-0.44 * * * \\
(1.65)\end{array}$ \\
\hline WW I & $\begin{array}{l}0.76^{*} \\
(4.02)\end{array}$ & $\begin{array}{l}0.66^{*} \\
(6.79)\end{array}$ & & \\
\hline WWII & $\begin{array}{l}1.80^{*} \\
(7.93)\end{array}$ & $\begin{array}{l}1.64^{*} \\
(13.07)\end{array}$ & $\begin{array}{c}1.51^{*} \\
(10.25)\end{array}$ & \\
\hline WWIIAftermath & $\begin{array}{l}0.76^{*} \\
(3.11)\end{array}$ & $\begin{array}{l}0.82 * \\
(6.47)\end{array}$ & $\begin{array}{r}0.74 * \\
(5.08)\end{array}$ & \\
\hline $\begin{array}{l}\text { FIXED EXCHANGE } \\
\text { RATES }\end{array}$ & $\begin{array}{l}-0.19^{* *} \\
(2.26)\end{array}$ & $\begin{array}{l}-0.15 * \\
(3.42)\end{array}$ & $\begin{array}{l}-0.16^{*} \\
(3.87)\end{array}$ & $\begin{array}{l}-0.20^{*} \\
(4.11)\end{array}$ \\
\hline SEATS & & $\begin{array}{l}1.62 * \\
(5.55) \\
\end{array}$ & $\begin{array}{l}0.66^{* *} \\
(2.16)\end{array}$ & $\begin{array}{l}0.55^{* * *} \\
(1.78)\end{array}$ \\
\hline $\begin{array}{l}\text { Statistics: } \\
\text { No. of Observations } \\
\text { Adj. } R^{2} \\
\text { D.W. } \\
\text { AIC criterion } \\
\text { Saikkonen adjustment factor }\end{array}$ & $\begin{array}{c}128 \\
0.93 \\
0.87 \\
-0.71 \\
0.523\end{array}$ & $\begin{array}{c}128 \\
0.95 \\
1.17 \\
-0.99 \\
0.876\end{array}$ & $\begin{array}{c}79 \\
0.94 \\
1.34 \\
-0.97 \\
1.194\end{array}$ & $\begin{array}{c}55 \\
0.60 \\
1.27 \\
-0.83 \\
1.40\end{array}$ \\
\hline
\end{tabular}

Notes: $*(* *)[* * *]$ significantly different from zero at $1(5)[10] \%$.

\# Saikkonen's (1991) estimator adjusts for inconsistency in the standard errors of the I(1) variables in the cointegrating equation by including the contemporaneous, lagged and led values of the first differences of right side variables (with the exception of the dummy variables WWI, WWII, WWIIAftermath, and the fixed exchange rate dummy). See also Hamilton (1994, 608-618). One lead and lag of each explanatory variable is used here, but only the coefficients of the level terms are relevant and so presented. Using two leads and lags gives similar results. The standard errors and t-statistics are adjusted for the presence of correlation among the innovations of the I(1) variables by a factor formed by the ratio of two standard errors: (a) the standard error of the augmented equation, divided by (b) the "long run standard error". 
Table 3a: Supplement to Table 3

Competition and Ideological Preferences: Do Conservatives Spend Less?

Estimated Coefficients and Associated F-test

\begin{tabular}{l|c|c|c} 
& $\mathbf{1 8 7 0 - 2 0 0 0}$ & $\mathbf{1 9 2 1 - \mathbf { 2 0 0 0 }}$ & $\mathbf{1 9 4 5 - \mathbf { 2 0 0 0 }}$ \\
\hline SEATS * LIBERAL & 1.62 & 0.77 & 0.74 \\
\hline SEATS * (1 - LIBERAL) & 1.62 & 0.66 & 0.64 \\
\hline F(df,df) & $\mathrm{F}(1,99)=0$ & $\mathrm{~F}(1,51)=1.25$ & $\mathrm{~F}(1,29)=0.43$
\end{tabular}

$\mathrm{F}(1,100)$ at $5 \%=3.94$

Notes: Based on adding partisanship interacted with SEATS in place of SEATS in the models of Table 3, columns 2 to 4 . The F-test considers whether the coefficients are significantly different from each other. LIBERAL $=1$ if a Liberal government in power, $=0$ if a Conservative Government in power. 
Figure 2

The Effect of Imperfect Political Competition on the Relative Size of Government $1950-2000$

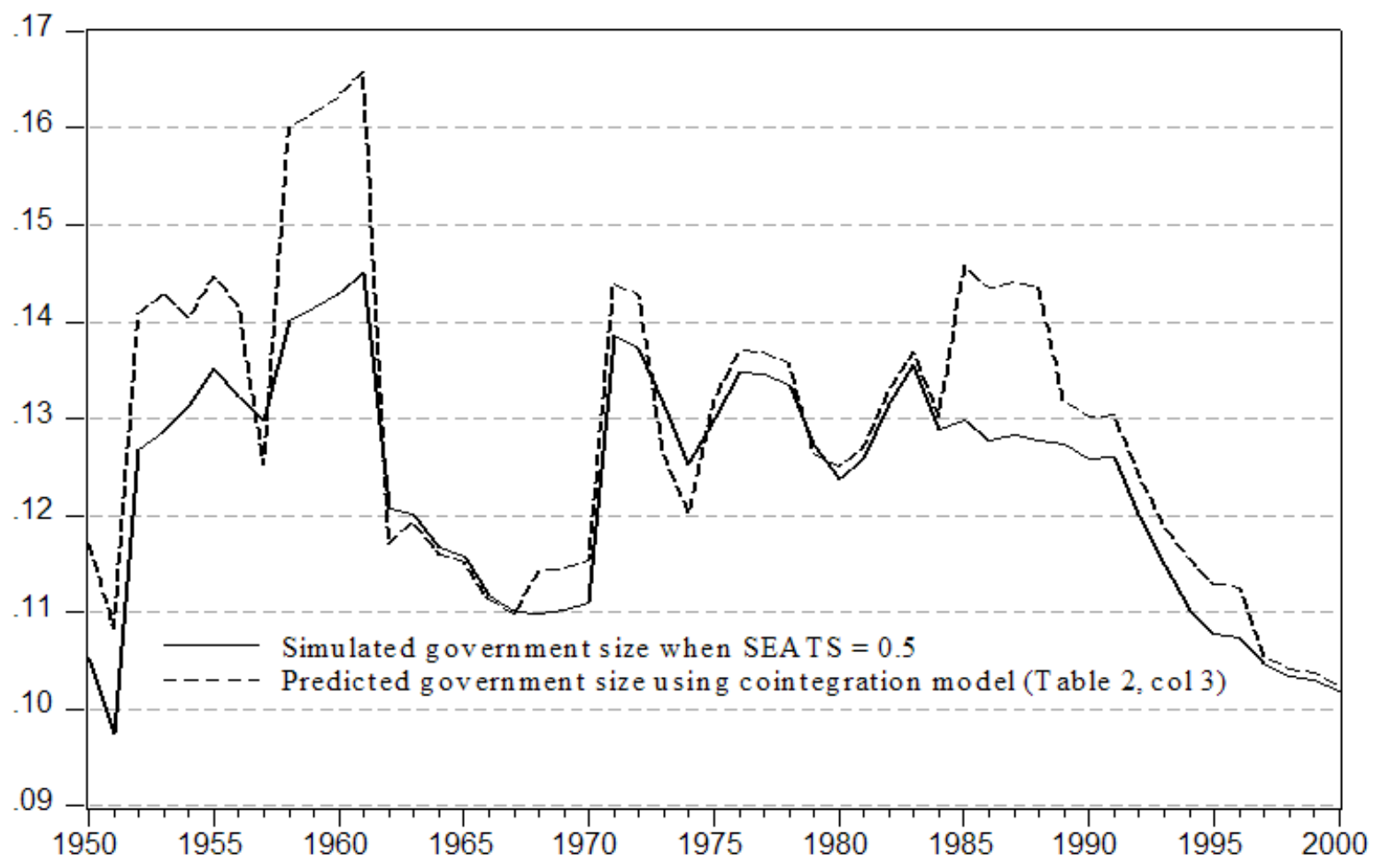

Notes: Based on Table 2, column 3.

Governments in less competitive periods: 1948-1957 - Liberal (St. Laurent);

1957-1963 - Conservative (Diefenbaker); 1984-1993 - Conservative (Mulroney);

1993-2003 - Liberal (Chretien) 
Table 4a

Shorter Run (Error Correction) Models of Government Size:

$1871-2000,1921-2000$ and $1946-2000$

(Absolute value of HAC t-statistics in brackets)

\begin{tabular}{|c|c|c|c|c|c|}
\hline $\begin{array}{l}\text { Dependent Variable: } \\
\text { D(LnGSIZE) }\end{array}$ & $\begin{array}{c}(1) \\
\text { Convergence } \\
1871-2000\end{array}$ & $\begin{array}{c}(2) \\
\text { Convergence } \\
1921-2000\end{array}$ & $\begin{array}{c}(3) \\
\text { Conditional } \\
\text { Convergence } \\
1871-2000\end{array}$ & $\begin{array}{c}(4) \\
\text { Conditional } \\
\text { Convergence } \\
1921-2000\end{array}$ & $\begin{array}{c}(5) \\
\text { Conditional } \\
\text { Convergence } \\
1946-2000\end{array}$ \\
\hline Error Correction term & $\begin{array}{l}-0.17 * * * \\
(1.71)\end{array}$ & $\begin{array}{l}-0.31 * * * \\
(1.95)\end{array}$ & $\begin{array}{l}-0.21 * * \\
(2.14)\end{array}$ & $\begin{array}{l}-0.31 * * * \\
(1.99)\end{array}$ & $\begin{array}{l}-0.27 * * * \\
(1.91)\end{array}$ \\
\hline D(LnAGRIC) & $\begin{array}{l}-0.45 \\
(1.53)\end{array}$ & $\begin{array}{l}-0.27 \\
(0.78)\end{array}$ & $\begin{array}{l}-0.41 \\
(1.54)\end{array}$ & $\begin{array}{l}-0.23 \\
(0.72)\end{array}$ & $\begin{array}{l}-0.02 \\
(0.08)\end{array}$ \\
\hline D(LnYOUNG) & $\begin{array}{l}-0.62 \\
(0.59)\end{array}$ & $\begin{array}{l}-0.55 \\
(0.50)\end{array}$ & $\begin{array}{l}-2.03 * * * \\
(1.70)\end{array}$ & $\begin{array}{l}-1.52 \\
(1.41)\end{array}$ & $\begin{array}{l}-1.20 \\
(1.28)\end{array}$ \\
\hline D(LnOPEN) & $\begin{array}{l}-0.20 \\
(1.15)\end{array}$ & $\begin{array}{l}-0.40 * * \\
(2.04)\end{array}$ & $\begin{array}{l}-0.15 \\
(0.89)\end{array}$ & $\begin{array}{l}-0.40 * * * \\
(1.97)\end{array}$ & $\begin{array}{l}-0.54^{* *} \\
(2.12)\end{array}$ \\
\hline Constant & $\begin{array}{l}-0.001 \\
(0.06) \\
\end{array}$ & $\begin{array}{c}0.01 \\
(0.52) \\
\end{array}$ & $\begin{array}{l}-0.19 * * \\
(2.01) \\
\end{array}$ & $\begin{array}{l}-0.14 \\
(1.54) \\
\end{array}$ & $\begin{array}{l}-0.12 \\
(1.41) \\
\end{array}$ \\
\hline WW I & $\begin{array}{c}0.06 \\
(1.28)\end{array}$ & & $\begin{array}{c}0.07 \\
(1.61)\end{array}$ & & \\
\hline WWIAfter & $\begin{array}{l}-0.18 * * \\
(2.47)\end{array}$ & & $\begin{array}{l}-0.19 * \\
(2.76) \\
\end{array}$ & & \\
\hline FIXED EXCHANGE RATES & $\begin{array}{c}0.03 \\
(1.53)\end{array}$ & $\begin{array}{c}0.03 \\
(1.07)\end{array}$ & $\begin{array}{c}0.03 \\
(1.66)\end{array}$ & $\begin{array}{l}0.04 * * * \\
(1.68)\end{array}$ & $\begin{array}{l}0.03 * * * \\
(1.77)\end{array}$ \\
\hline D(LnGRANT_SHARE) & $\begin{array}{l}-0.42 * \\
(4.04)\end{array}$ & $\begin{array}{l}-0.37 * \\
(3.50)\end{array}$ & $\begin{array}{l}-0.39 * \\
(3.77)\end{array}$ & $\begin{array}{l}-0.35^{*} \\
(3.38)\end{array}$ & $\begin{array}{l}-0.60 * \\
(6.84)\end{array}$ \\
\hline SEATS & & & $\begin{array}{l}0.30 * * \\
(2.16)\end{array}$ & $\begin{array}{c}0.25 \\
(1.65)\end{array}$ & $\begin{array}{c}0.21 \\
(1.61)\end{array}$ \\
\hline $\begin{array}{l}\text { Statistics: } \\
\text { No. of Observations } \\
\text { Adj. } \mathrm{R}^{2} \\
\text { D.W. } \\
\text { Serial Corr. LM test } \mathrm{N}^{*} \mathrm{R}^{2} \\
\text { (2lags) } \\
\text { AIC criterion }\end{array}$ & $\begin{array}{l}130 \\
0.63 \\
1.81 \\
6.65^{* *} \\
-1.70\end{array}$ & $\begin{array}{c}79 \\
0.65 \\
1.81 \\
2.35 \\
-1.70\end{array}$ & $\begin{array}{c}130 \\
0.65 \\
1.83 \\
3.98 \\
-1.75\end{array}$ & $\begin{array}{c}79 \\
0.67 \\
1.86 \\
0.94 \\
-1.73\end{array}$ & $\begin{array}{l}55 \\
0.79 \\
1.39 \\
6.79 * * \\
-2.55\end{array}$ \\
\hline
\end{tabular}

Notes: * $(* *)[* * *]$ significant at $1 \%(5 \%)(10 \%)$. The error correction term used in each column is based on the corresponding column in Table 2 except in the case of the model for 1946 - 2000 which is not shown in Table 2. 
Table 4b

Shorter Run (Error Correction) Models of Government Size Using 3 Lags

$1874-2000,1922-2000$ and $1946-2000$

(Absolute value of HAC t-statistics in brackets)

\begin{tabular}{|c|c|c|c|c|c|}
\hline $\begin{array}{l}\text { Dependent Variable } \\
\text { D(LnGSIZE) }\end{array}$ & $\begin{array}{c}(1) \\
\text { Convergence in } \\
\text { S.R. } \\
1874-2000\end{array}$ & $\begin{array}{c}(2) \\
\text { Convegence in } \\
\text { S.R. } \\
1922-2000\end{array}$ & $\begin{array}{c}(3) \\
\text { Conditional } \\
\text { Convergence in } \\
\text { S.R. } \\
1874-\mathbf{2 0 0 0}\end{array}$ & $\begin{array}{c}(4) \\
\text { Conditional } \\
\text { Convergence in } \\
\text { S.R. } \\
\text { 1922 - } 2000 \\
\end{array}$ & $\begin{array}{c}(5) \\
\text { Conditional } \\
\text { Convergence } \\
\text { in S.R. } \\
\text { 1946 - 2000 }\end{array}$ \\
\hline Error Correction term & $-0.11(1.15)$ & $-0.19(1.05)$ & $-0.15(1.53)$ & $-0.21(1.15)$ & $-0.14(0.96)$ \\
\hline $\begin{array}{l}\text { D(LnRYPC }) \\
\text { - lags } 1-3\end{array}$ & $\begin{array}{l}-0.76 * *(2.60) \\
0.26(1.09) \\
0.02(0.11) \\
-0.35 * * *(1.80)\end{array}$ & $\begin{array}{r}-0.57(1.14) \\
0.22(0.77) \\
-0.23(0.94) \\
-0.39(1.28)\end{array}$ & $\begin{array}{l}-0.84 *(3.17) \\
0.15(0.69) \\
-0.06(0.28) \\
-0.36 * * *(1.90)\end{array}$ & $\begin{array}{l}-0.67(1.44) \\
0.14(0.52) \\
-0.32(1.33) \\
-0.37(1.29)\end{array}$ & $\begin{array}{l}-0.03(0.06) \\
-0.23(0.43) \\
-0.97(1.27) \\
-1.10^{* *}(2.18)\end{array}$ \\
\hline $\begin{array}{l}\text { D(LnAGRIC) } \\
- \text { lags } 1 \text { - } 3\end{array}$ & $\begin{array}{l}-0.25(0.88) \\
-0.75^{* *}(2.54) \\
-0.24(0.88) \\
0.22(0.86)\end{array}$ & $\begin{array}{l}-0.19(0.58) \\
-0.63 * *(2.13) \\
-0.52 * * *(1.80) \\
0.21(0.80)\end{array}$ & $\begin{array}{l}-0.21(0.75) \\
-0.76^{*}(2.65) \\
-0.24(0.87) \\
0.24(0.93)\end{array}$ & $\begin{array}{l}-0.13(0.41) \\
-0.64 * *(2.23) \\
-0.47(1.56) \\
0.31(1.12)\end{array}$ & $\begin{array}{l}0.05(0.15) \\
-0.51 * * *(1.91) \\
-1.11 * *(2.38) \\
-0.21(0.64)\end{array}$ \\
\hline $\begin{array}{l}\text { D(LnYOUNG) } \\
-\operatorname{lags} 1-3\end{array}$ & $\begin{array}{r}-1.54(0.54) \\
4.45(1.11) \\
-3.54(1.10) \\
-0.99(0.45)\end{array}$ & $\begin{array}{r}-1.95(0.57) \\
4.07(0.92) \\
-0.10(0.03) \\
-3.79(1.46)\end{array}$ & $\begin{array}{r}-3.95(1.26) \\
4.19(1.12) \\
-3.15(1.04) \\
0.18(0.08)\end{array}$ & $\begin{array}{l}-4.72(1.33) \\
4.59(1.03) \\
-0.30(0.11) \\
-2.31(0.86)\end{array}$ & $\begin{array}{l}-7.86 *(2.97) \\
4.05(1.22) \\
4.19(1.39) \\
-3.20 * * *(1.81)\end{array}$ \\
\hline $\begin{array}{l}\text { D(LnIMRATIO) } \\
\text { - lags 1-3 }\end{array}$ & $\begin{array}{l}-0.10 *(2.96) \\
-0.02(0.48) \\
-0.009(0.28) \\
0.04(1.36)\end{array}$ & $\begin{array}{l}-0.16^{*}(5.03) \\
-0.005(0.08) \\
-0.05(1.03) \\
-0.0007(0.02)\end{array}$ & $\begin{array}{l}-0.09 * *(2.58) \\
-0.009(0.21) \\
0.0006(0.02) \\
0.04(1.57)\end{array}$ & \begin{tabular}{|l}
$-0.14 *(4.02)$ \\
$0.01(0.20)$ \\
$-0.04(0.85)$ \\
$0.006(0.16)$
\end{tabular} & $\begin{array}{l}-0.09 * *(2.62) \\
0.08(1.67) \\
-0.01(0.24) \\
0.02(0.51)\end{array}$ \\
\hline $\begin{array}{l}\text { D(LnOPEN) } \\
\text { - lags 1-3 }\end{array}$ & $\begin{array}{c}-0.05(0.22) \\
-0.62 *(3.12) \\
0.03(0.12) \\
-0.08(0.44)\end{array}$ & $\begin{array}{r}-0.39(1.40) \\
-0.27(1.04) \\
-0.25(0.94) \\
0.07(0.28)\end{array}$ & $\begin{array}{c}-0.01(0.07) \\
-0.54 *(2.78) \\
0.04(0.16) \\
-0.11(0.65)\end{array}$ & \begin{tabular}{|l|}
$-0.41(1.53)$ \\
$-0.27(1.03)$ \\
$-0.26(0.95)$ \\
$0.01(0.05)$
\end{tabular} & $\begin{array}{l}-0.40 * *(2.10) \\
-0.13(0.78) \\
-0.12(0.67) \\
-0.10(0.69)\end{array}$ \\
\hline Constant & $-0.02(0.86)$ & $-0.03(1.00)$ & $-0.18 * *(2.11)$ & $-0.17 * * *(2.00)$ & $-0.18 *(3.16)$ \\
\hline WWI & $0.11^{* * *}(1.95)$ & & $0.13 * *(2.29)$ & & \\
\hline WWIAfter & $-0.18 *(2.64)$ & & $-0.21 *(3.10)$ & & \\
\hline WWII & $0.18 *(2.88)$ & $0.18^{* *}(2.58)$ & $0.17 *(3.21)$ & $0.17 * *(2.64)$ & $0.49 * *(2.51)$ \\
\hline WWIIAfter & $-0.28 *(3.97)$ & $-0.26 *(3.16)$ & $-0.26 *(3.84)$ & $-0.27 *(3.14)$ & $-0.26 *(5.26)$ \\
\hline $\begin{array}{l}\text { FIXED EXCHANGE } \\
\text { RATES }\end{array}$ & $0.03^{* * *}(1.75)$ & $0.05^{* * *}(1.83)$ & $0.03 * *(2.00)$ & $0.06^{* *}(2.22)$ & $0.02(1.01)$ \\
\hline D(LnGRANT_SHARE) & $-0.43 *(4.47)$ & $-0.38 *(3.27)$ & $-0.41 *(4.25)$ & $-0.37 *(3.23)$ & $-0.64 *(8.07)$ \\
\hline SEATS & & & $0.25 * *(2.03)$ & $0.25 * * *(1.74)$ & $0.25 * *(2.68)$ \\
\hline $\begin{array}{l}\text { Statistics: } \\
\text { No. of Observations } \\
\text { Adj. } \mathrm{R}^{2} \\
\text { D.W. } \\
\text { Serial Corr. LM test } \mathrm{N}^{*} \mathrm{R}^{2} \\
\text { (2 lags) } \\
\text { AIC criterion }\end{array}$ & $\begin{array}{l}127 \\
0.67 \\
1.97 \\
9.11^{* *} \\
-1.70\end{array}$ & $\begin{array}{c}79 \\
0.66 \\
2.14 \\
3.43 \\
-1.60\end{array}$ & $\begin{array}{l}127 \\
0.68 \\
1.99 \\
6.75^{* *} \\
-1.72\end{array}$ & $\begin{array}{c}79 \\
0.68 \\
2.20 \\
2.58 \\
-1.63\end{array}$ & $\begin{array}{c}55 \\
0.85 \\
1.90 \\
1.59 \\
-2.79\end{array}$ \\
\hline
\end{tabular}

Notes: $*(* *)[* *]$ significant at $1 \%(5 \%)(10 \%)$.

Lag lengths from 1 to 3 do not alter conclusions about role of political factors LIBERAL, MINORITY, DURATION and ELECTIONYEAR(-1). The error correction term used in each column its based on the corresponding column in Table 2, except in the case of the model for $1946-2000$ which is not shown in Table 2. 
Table 4b(I).

Supplement to Table $4 \mathrm{~b}$

Competition and Ideological Preferences: Do Conservatives Spend Less?

Estimated Coefficients and Associated F-test

\begin{tabular}{l|c|c|c} 
& $\mathbf{1 8 7 4 - 2 0 0 0}$ & $\mathbf{1 9 2 2} \mathbf{- 2 0 0 0}$ & $\mathbf{1 9 4 6 - \mathbf { 2 0 0 0 }}$ \\
\hline SEATS * LIBERAL & 0.28 & 0.32 & 0.36 \\
\hline $\begin{array}{l}\text { SEATS * } \mathbf{1}- \\
\text { LIBERAL) }\end{array}$ & 0.25 & 0.25 & 0.28 \\
\hline F(df,df) & $\mathrm{F}(1,97)=0$ & $\mathrm{~F}(1,51)=1.25$ & $\mathrm{~F}(1,27)=0.43$
\end{tabular}

$\mathrm{F}(1,100)$ at $5 \%=3.94$

Notes: see Table 3a. Based on adding partisanship interacted with SEATS in place of SEATS in the models of Table $4 \mathrm{~b}$, columns 3 to 5 . 
Table 5

Detrending and Alternative Models of the Short Run, Various Sample Periods

(Absolute value of Newey-West HAC t-statistics in brackets)

\begin{tabular}{|c|c|c|c|c|c|c|}
\hline \multicolumn{7}{|c|}{$1871-2000$} \\
\hline $\begin{array}{l}\text { Dependent variable } \\
\text { (form of economic factors) }\end{array}$ & $\begin{array}{c}(1) \\
\text { D(LnGSIZE) } \\
\text { (Dlog form) }\end{array}$ & $\begin{array}{c}\text { (2) } \\
\text { LnGSIZE } \\
\text { (Log form) }\end{array}$ & $\begin{array}{c}\text { (3) } \\
\text { D(LnGSIZE) } \\
(\text { Dlog form) }\end{array}$ & \begin{tabular}{|c|} 
(4) $1875-1995$ \\
HPcycle (LnGSIZE) \\
( Dlog form)
\end{tabular} & \begin{tabular}{|c|} 
(5) $1875-1995$ \\
HPcycle (LnGSIZE) \\
(HPcycle form)
\end{tabular} & $\begin{array}{c}\text { (6) } \\
\text { LnGSIZE } \\
\text { ( Dlog form) }\end{array}$ \\
\hline $\begin{array}{l}\text { Error correction term } \\
\text { LnGSIZE - 1 } \\
\text { D(LnGSIZE) -1 } \\
\text { HPcycle(LnGSIZE) - } 1 \\
\text { HPcycle(LnGSIZE) - } 1 \\
\text { HPtrend(LnGSIZE) }\end{array}$ & $\begin{array}{c}-0.223^{* *} \\
(2.17) \\
- \\
- \\
- \\
-\end{array}$ & $\begin{array}{c}- \\
0.677^{*} \\
(12.14) \\
- \\
- \\
- \\
-\end{array}$ & $\begin{array}{c}- \\
- \\
0.096 \\
(0.90) \\
- \\
- \\
-\end{array}$ & $\begin{array}{c}- \\
- \\
- \\
0.694^{*} \\
(7.07) \\
- \\
-\end{array}$ & $\begin{array}{c}- \\
- \\
- \\
- \\
-0.027 \\
(0.82) \\
-\end{array}$ & $\begin{array}{c}- \\
- \\
- \\
- \\
- \\
- \\
0.966^{*} \\
(18.60)\end{array}$ \\
\hline SEATS & $\begin{aligned} 0.395^{* * *} \\
(2.25) \\
\end{aligned}$ & $\begin{array}{c}0.523 * * \\
(2.35) \\
\end{array}$ & $\begin{array}{c}0.274 * * * \\
(1.72) \\
\end{array}$ & $\begin{array}{l}0.004 \\
(0.02) \\
\end{array}$ & $\begin{array}{l}-0.049 \\
(1.26) \\
\end{array}$ & $\begin{array}{l}-0.192 \\
(0.58) \\
\end{array}$ \\
\hline MINORITY & $\begin{array}{l}0.035 \\
(1.09) \\
\end{array}$ & $\begin{array}{r}-0.019 \\
(0.43) \\
\end{array}$ & $\begin{array}{l}0.025 \\
(0.90) \\
\end{array}$ & $\begin{array}{l}0.002 \\
(0.07) \\
\end{array}$ & $\begin{array}{l}-0.036 \\
(1.50) \\
\end{array}$ & $\begin{array}{l}-0.052 \\
(0.76) \\
\end{array}$ \\
\hline ELECTIONYEAR - 1 & $\begin{array}{c}-0.0004 \\
(0.02) \\
\end{array}$ & $\begin{array}{l}-0.022 \\
(0.96) \\
\end{array}$ & $\begin{array}{l}0.003 \\
(0.13) \\
\end{array}$ & $\begin{array}{r}-0.011 \\
(0.54) \\
\end{array}$ & $\begin{array}{l}-0.002 \\
(0.24) \\
\end{array}$ & $\begin{array}{l}-0.028 \\
(1.26) \\
\end{array}$ \\
\hline DURATION & $\begin{array}{l}-0.003 \\
(0.65) \\
\end{array}$ & $\begin{array}{l}-0.003 \\
(0.52) \\
\end{array}$ & $\begin{array}{l}0.0009 \\
(0.20) \\
\end{array}$ & $\begin{array}{c}-0.0008 \\
(0.15) \\
\end{array}$ & $\begin{array}{l}-0.002 \\
(0.78) \\
\end{array}$ & $\begin{array}{l}-0.004 \\
(0.40) \\
\end{array}$ \\
\hline LIBERAL & $\begin{array}{l}0.026 \\
(0.92) \\
\end{array}$ & $\begin{array}{l}0.013 \\
(0.36) \\
\end{array}$ & $\begin{array}{l}0.013 \\
(0.49) \\
\end{array}$ & $\begin{array}{l}0.0009 \\
(0.04)\end{array}$ & $\begin{array}{l}0.006 \\
(0.55) \\
\end{array}$ & $\begin{array}{l}-0.007 \\
(0.15) \\
\end{array}$ \\
\hline $\begin{array}{l}\text { Statistics: } \\
\text { No. of Observations } \mathrm{N} \\
\text { Adj. } \mathrm{R}^{2} \\
\text { Ser. Corr. LM test } \mathrm{N}^{*} \mathrm{R}^{2} \\
\text { (2lags) - P value } \\
\end{array}$ & $\begin{array}{c}130 \\
0.648 \\
0.136\end{array}$ & $\begin{array}{c}130 \\
0.968 \\
0.003\end{array}$ & $\begin{array}{c}129 \\
0.614 \\
0.624\end{array}$ & $\begin{array}{c}121 \\
0.827 \\
0.214\end{array}$ & $\begin{array}{c}121 \\
0.974 \\
0.000\end{array}$ & $\begin{array}{c}130 \\
0.950 \\
0.000\end{array}$ \\
\hline \multicolumn{7}{|c|}{$1922-2000$} \\
\hline & $(7)$ & $(8)$ & (9) & (10) 1922-1995 & (11) $1922-1995$ & (12) \\
\hline Error correction term & $\begin{array}{c}-0.343 * * \\
(2.04)\end{array}$ & - & - & - & - & - \\
\hline LnGSIZE - 1 & - & $\begin{array}{l}0.693 * \\
(8.78)\end{array}$ & - & - & - & - \\
\hline D(LnGSIZE) -1 & - & - & $\begin{array}{l}0.240^{* *} \\
(2.41)\end{array}$ & - & - & - \\
\hline HPcycle(LnGSIZE) - 1 & - & - & - & $\begin{array}{l}0.562^{*} \\
(4.80)\end{array}$ & & - \\
\hline HPcycle(LnGSIZE) - 1 & - & - & - & - & $\begin{array}{l}-0.046 \\
(0.96)\end{array}$ & - \\
\hline HPtrend(LnGSIZE) & - & - & - & - & - & $\begin{array}{l}1.113^{*} \\
(23.72) \\
\end{array}$ \\
\hline SEATS & $\begin{array}{c}0.348^{* *} \\
(2.02) \\
\end{array}$ & $\begin{array}{l}0.301 \\
(1.36)\end{array}$ & $\begin{array}{l}0.229 \\
(1.54)\end{array}$ & $\begin{array}{l}-0.173 \\
(0.81)\end{array}$ & $\begin{array}{l}-0.067 \\
(1.51)\end{array}$ & $\begin{array}{c}-0.687 * * * \\
(1.99)\end{array}$ \\
\hline MINORITY & $\begin{array}{l}0.029 \\
(0.73) \\
\end{array}$ & $\begin{array}{r}-0.015 \\
(0.33) \\
\end{array}$ & $\begin{array}{l}0.009 \\
(0.29) \\
\end{array}$ & $\begin{array}{r}-0.009 \\
(0.23) \\
\end{array}$ & $\begin{array}{r}-0.042 \\
(1.54) \\
\end{array}$ & $\begin{array}{l}-0.053 \\
(0.99) \\
\end{array}$ \\
\hline ELECTIONYEAR - 1 & $\begin{array}{l}0.030 \\
(1.22) \\
\end{array}$ & $\begin{array}{c}-0.059 * * \\
(2.34) \\
\end{array}$ & $\begin{array}{l}-0.035 \\
(1.24) \\
\end{array}$ & $\begin{array}{l}-0.038 \\
(1.37) \\
\end{array}$ & $\begin{array}{l}-0.003 \\
(0.39) \\
\end{array}$ & $\begin{array}{l}-0.042 \\
(1.54) \\
\end{array}$ \\
\hline DURATION & $\begin{array}{l}-0.009 \\
(1.02) \\
\end{array}$ & $\begin{array}{r}-0.003 \\
(0.37) \\
\end{array}$ & $\begin{array}{l}-0.001 \\
(0.24) \\
\end{array}$ & $\begin{array}{l}0.0008 \\
(0.12)\end{array}$ & $\begin{array}{l}-0.003 \\
(0.68) \\
\end{array}$ & $\begin{array}{l}0.0003 \\
(0.03) \\
\end{array}$ \\
\hline LIBERAL & $\begin{array}{l}0.056 \\
(1.62)\end{array}$ & $\begin{array}{c}0.082 * * * \\
(1.75)\end{array}$ & $\begin{array}{l}0.018 \\
(0.53) \\
\end{array}$ & $\begin{array}{l}-0.010 \\
(0.30)\end{array}$ & $\begin{array}{l}-0.003 \\
(0.13)\end{array}$ & $\begin{array}{l}-0.061 \\
(1.26)\end{array}$ \\
\hline $\begin{array}{l}\text { Statistics: } \\
\text { No. of Observations } \mathrm{N} \\
\text { Adj. } \mathrm{R}^{2} \\
\text { Ser. Corr. LM test } \mathrm{N}^{*} \mathrm{R}^{2} \\
\text { (2lags) - P value } \\
\end{array}$ & $\begin{array}{c}79 \\
0.664 \\
0.631\end{array}$ & $\begin{array}{c}79 \\
0.963 \\
0.039\end{array}$ & $\begin{array}{c}79 \\
0.612 \\
0.083\end{array}$ & $\begin{array}{c}74 \\
0.858 \\
0.315\end{array}$ & $\begin{array}{c}74 \\
0.970 \\
0.000\end{array}$ & $\begin{array}{c}79 \\
0.954 \\
0.019\end{array}$ \\
\hline
\end{tabular}


Figure 4

Explicit Modelling of the Long Run versus Using a Lag or a Hodrick-Prescott Trend

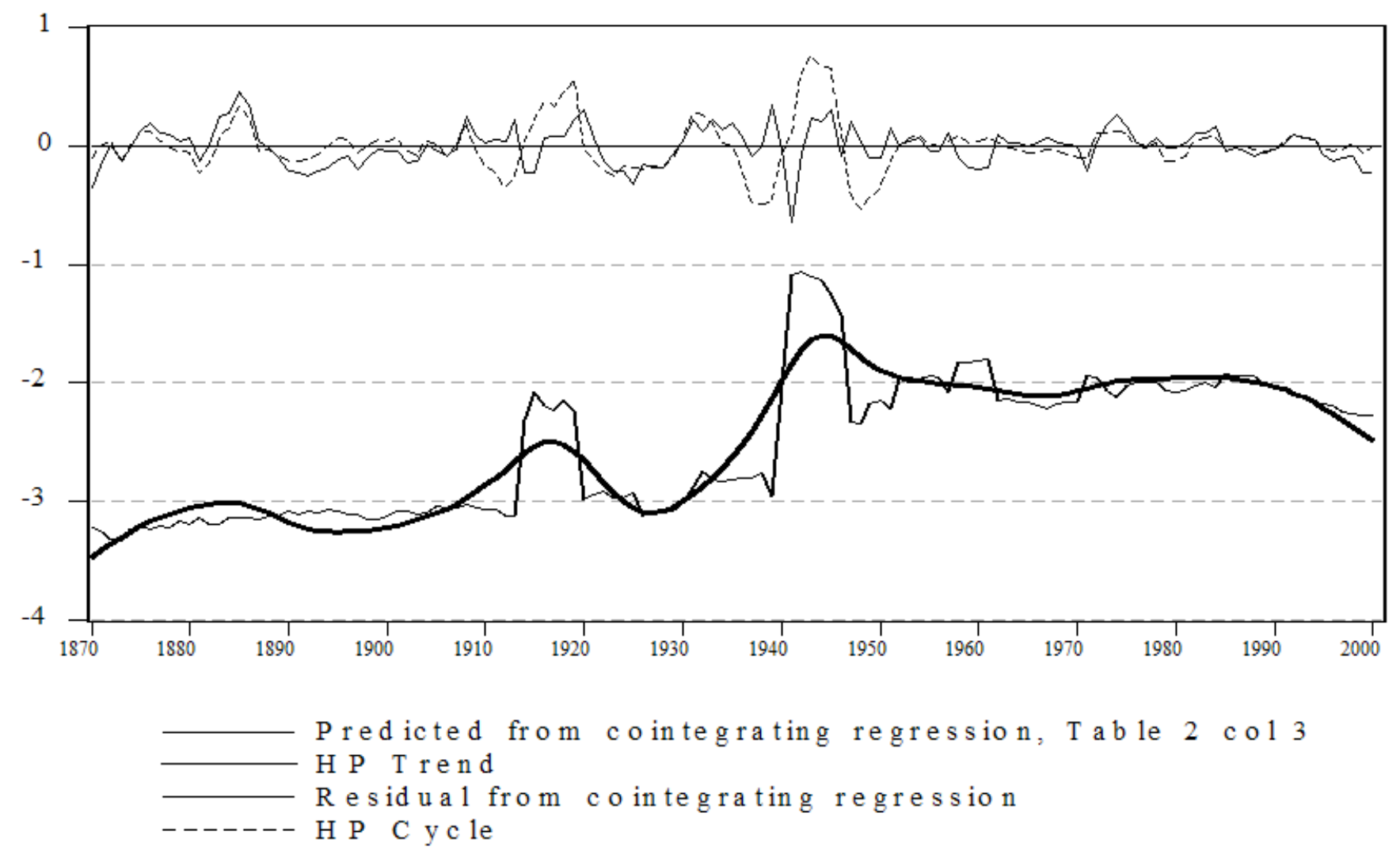

1871 - 2000

\begin{tabular}{ccccc}
\hline For LnGSIZE & $\begin{array}{c}\text { Predicted value from } \\
\text { cointegration } \\
\text { regression, } \\
\text { Table 3, col 3 }\end{array}$ & $\begin{array}{c}\text { Residual from } \\
\text { cointegrating } \\
\text { regression }\end{array}$ & $\begin{array}{c}\text { HP Trend } \\
\mathbf{( 1 0 0 + )}\end{array}$ & HP Cycle \\
\hline Mean & -2.52 & 0.00 & -2.52 & 0.00 \\
Std. Dev. & $\mathbf{0 . 5 8}$ & 0.16 & $\mathbf{0 . 5 4}$ & 0.21 \\
Skewness & $\mathbf{0 . 3 7}$ & -0.17 & $\mathbf{- 0 . 0 6}$ & 0.78 \\
Sum Sq. Dev. & $\mathbf{4 4 . 2 6}$ & 3.35 & $\mathbf{3 8 . 3 1}$ & 5.70 \\
Observations & 131.00 & 131.00 & 131.00 & 131.00 \\
\hline \multicolumn{5}{c}{$\mathbf{1 9 4 6}-\mathbf{2 0 0 0}$} \\
\hline For LnGSIZE & Predicted value from & Residual from & & \\
& cointegration & cointegrating & HP Trend (100) & HP Cycle \\
regression, & regression & & \\
\hline Mable 3, col 3 & -2.06 & 0.00 & -2.06 \\
Std. Dev. & $\mathbf{0 . 1 3}$ & 0.11 & $\mathbf{0 . 1 2}$ & 0.11 \\
Skewness & $\mathbf{- 0 . 7 7}$ & 1.51 & $\mathbf{- 2 . 0 2}$ & 1.07 \\
Sum Sq. Dev. & $\mathbf{0 . 8 8}$ & 0.69 & $\mathbf{0 . 7 5}$ & 0.65 \\
Observations & 55 & 55 & 55 & 55 \\
\hline
\end{tabular}

Notes: + '100' refers to the parameter of the Hodrick - Prescott filter usually employed with annual data. 


\section{References}

Adams, J., S. Merrill and B. Grofman (2005). The Unified Theory of Party Competition. Cambridge 2005.

Alesina, A. and N. Roubini, with G.D. Cohen (1997) Political Business Cycles and the Macroeconomy. MIT Press.

Besley, T., T. Persson and D. Sturm (2005). "Political Competition and Economic Performance: Theory and Evidence from the United States". London School of Economics, Unpublished.

Bird, R. (1970). The Growth of Government Spending in Canada. Toronto: Canadian Tax Foundation.

Borcherding, T. E. (1985) "The Causes of Government Expenditure Growth: A Survey of the U.S. Evidence", Journal of Public Economics 28, 359 - 382.

Borcherding, T. E., J. S. Ferris and A. Garzoni (2004) "Changes in the Real Size of Government Since 1970", in Juergen Backhaus and Richard Wagner (eds.). Kluwer Handbook in Public Finance. Kluwer Academic Press, 77-108.

Brender, A. and A. Drazen (2005). "Political Budget Cycles in New versus Established Democracies." Journal of Monetary Economics 52, 1271-95.

Breton, A. (1996). Competitive Governments: An Economic Theory of Politics and Public Finance. Cambridge University Press.

Cameron, D. (1978). "The Expansion of the Public Economy." American Political Science Review 72, 1243-1261.

Canova, F. (1998). "Detrending and Business Cycle Facts". Journal of Monetary Economics 41, 475-512.

Cox, G. and M. C. Munger (1989). "Contributions, Expenditure, Turnout: The 1982 U.S. House Elections." American Political Science Review 83, 217-231.

Drazen, A. (2001). "The Political Business Cycle After 25 Years". In B. Bernanke and K. Rogoff (eds.), NBER Macroeconomics Annual 2000. MIT Press, 75 - 117.

Dudley, L. and U. Witt (2004). "Arms and the Man: World War I and the Rise of the Welfare State", University of Montreal, Unpublished.

Endersby, J., S. Galatas and C. Rackaway (2002). "Closeness Counts in Canada: Voter Participation in the 1993 and 1997 Federal Elections." Journal of Politics 64(2), 610-631.

Engle, R.F. and C.W.J. Granger (1987) "Co-integration and Error Correction: Representation, Estimation, and Testing." Econometrica 55(2), 251-276.

Ferris, J. S. and E. G. West (1996) "Testing Theories of Real Government Size: U. S. Experience, 1959 1989," Southern Economic Journal 62, 537-553.

Ferris, J. S. and S. L. Winer (2003) "Searching for Keynes: With Application to Canada, 1870 - 2000", CESifo Working Paper No. 1016.

Ferris, J. S. and S. L. Winer (2006a). " Political Competition and Convergence to Fundamentals: With Application to the Political Business Cycle and the Size of Government: CESifo Working Paper No. 1646, January. Also at www.ssrn.com

Ferris, J. S. and S. L. Winer (2006b). "Just how much bigger is government in Canada?" Carleton University Working Paper, Revised October. At www.carleton.ca/ winers

Filer, J.E. and L. Kenny (1980). "Voter Turnout and the Benefits of Voting". Public Choice 
$35(5), 575-585$.

Franklin, M. (2004). Voter Turnout and the Dynamics of Electoral Competition in Established Democracies Since 1945. Cambridge University Press.

Gillespie, W. I. (1991) Tax, Borrow and Spend: Financing Federal Spending in Canada, 1867-1990. Carleton Library Series, no. 170. Ottawa: Carleton University Press.

Gregory, A. W. and B. E. Hansen (1996) "Residual-Based Tests for Cointegration in Models with Regime Shifts," Journal of Econometrics 70(1), 99-126.

Hamilton, J. D. (1994). Time Series Analysis. Princeton University Press.

Haynes S.E. and J. A. Stone (1990). "Political Models of the Business Cycle Should Be Revived." Economic Inquiry, 28(3), 442-65.

Heckelman, J.C. (2002) "Electoral Uncertainty and the Macroeconomy: The Evidence from Canada", Public Choice 113, 179-189.

Heckelman, J.C. (2006). "Another Look at the Evidence for Rational Partisan Cycles." Public Choice 126, 257-274.

Hettich, W. and S. L. Winer (1999). Democratic Choice and Taxation. Cambridge University Press.

Hibbs, D. (1977). "Political Parties and Macroeconomic Policy". American Political Science Review 71, 1467- 1487.

Kau, J. B. and P. H. Rubin (1981). "The Size of Government". Public Choice 37, 261-74.

Kneebone, R. D. and K. J. McKenzie (1999) Past (In) Discretions: Canadian Federal and Provincial Fiscal Policy. University of Toronto Press.

Kneebone, R.D. and K.J. McKenzie (2001) "Electoral and Partisan Cycles in Fiscal Policy: An examination of Canadian provinces" International Tax and Public Finance 8, 753-74.

Kontopolous, Y. and R. Perotti (1999). "Government Fragmentation and Fiscal Policy Outcomes: Evidence from OECD Countries". in J. Poterba J. von Hagen (eds.) Fiscal Institutions and Fiscal Performance. University of Chicago Press, 81-102.

Legrenzi, G. (2004).“The Displacement Effect in the Growth of Governments”. Public Choice 120, 191-204.

Levitt, S. D. and J. M. Poterba (1999) "Congressional Distributive Politics and State Economic Performance", Public Choice 99, 185 - 215.

MacKinnon, J. G. (1996). "Numerical Distribution Functions for Unit Root and Cointegration Tests". Journal of Applied Econometrics 11(6), 601-618.

Mayhew, D. R. (1974). "Congressional Elections: The Case of the Vanishing Marginals". Polity 6(3), 295-317.

Mink, M. and J. De Haan (2005). "Has the Stability and Growth Pact Impeded Political Budget Cycles in the European Union?". Cesifo Working Paper 1532, September.

Myrdal, G., (1960). Beyond the Welfare State. Bantam Books.

Mueller, D.C. (2003). Public Choice III. Cambridge University Press.

Nordhaus, W. (1975). “The Political Business Cycle”. Review of Economic Studies 42, 169-90.

Peacock, A. and J. Wiseman (1961). The Growth of Public Expenditure in the United Kingdom. Princeton University Press.

Persson, T., G. Roland and G. Tabellini (2004). "How do Electoral Rules Shape Party Structures, 
Government Coalitions, and Economic Policies." CESifo Working Paper No. 1115.

Persson, T., and G. Tabellini (2003). "Do Electoral Cycles Differ Across Political Systems?" Working Paper 232, IGIER, University of Bocconi, March.

Reid, B. (1998). "Endogenous Elections, Electoral Budget Cycles and Canadian Provincial Governments". Public Choice 97(1), 35-48.

Remmer K. L. and E. Wibbels (2000). "The Subnational Politics of Economic Adjustment". Comparative Political Studies 33(4), 419-51.

Rodrik, D. (1998). “Why Do More Open Economies Have Bigger Governments?” Journal of Political Economy 106, 997-1032.

Rogoff, K., and A. Sibert (1988). "Elections and Macroeconomic Policy Cycles". Review of Economic Studies 91(1), 1 - 16.

Saikkonen, P. (1991). “Asymptotically Efficient Estimation of Cointegration Regressions”, Econometric Theory 7(1), 1-21.

Serletis, A. and P.C. Afxentiou (1998). "Electoral and Partisan Cycle Regularities in Canada." Canadian Journal of Economics 31(1), 28-46.

Shi, M. and J. Svensson (2006). "Political Budget Cycles: Do They Differ Across Countries and Why?" Journal of Public Economics, 90(8-9), 1367 - 1389.

Solé-Ollé, A. (2006). "The Effects of Party Competition on Budget Outcomes: Empirical Evidence from Local Governments in Spain", Public Choice 126(1-2), 145-176.

Stock, J. H. and M. W. Watson (1993). "A Simple Estimator of Cointegrating Vectors in HigherOrder Integrated Systems", Econometrica 61(4), 783-820.

Tellier, G., (2006). "Public expenditures in Canadian provinces: An empirical study of politico-economic interactions". Public Choice 126(3-4), 367 - 385.

Weingast, B., K. Shepsle and C. Johnsen (1981). "The Political Economy of Benefits and Costs: A Neoclassical Approach to Distributive Politics". Journal of Political Economy 89, 642 - 64.

Wittman, D. ((1995). The Myth of Democratic Failure: Why Political Insitutions Are Efficient. University of Chicago Press.

Zhou, S., (2001). "The Power of Cointegration Tests versus Data Frequency and Time Spans". Southern Economic Journal 67(4), 906 - 921. 